In cooperation with the Houston-Galveston Area Council and Texas Commission on Environmental Quality

Water-Quality, Stream-Habitat, and Biological Data for West Fork Double Bayou, Cotton Bayou, and Hackberry Gully, Chambers County, Texas, 2006-07

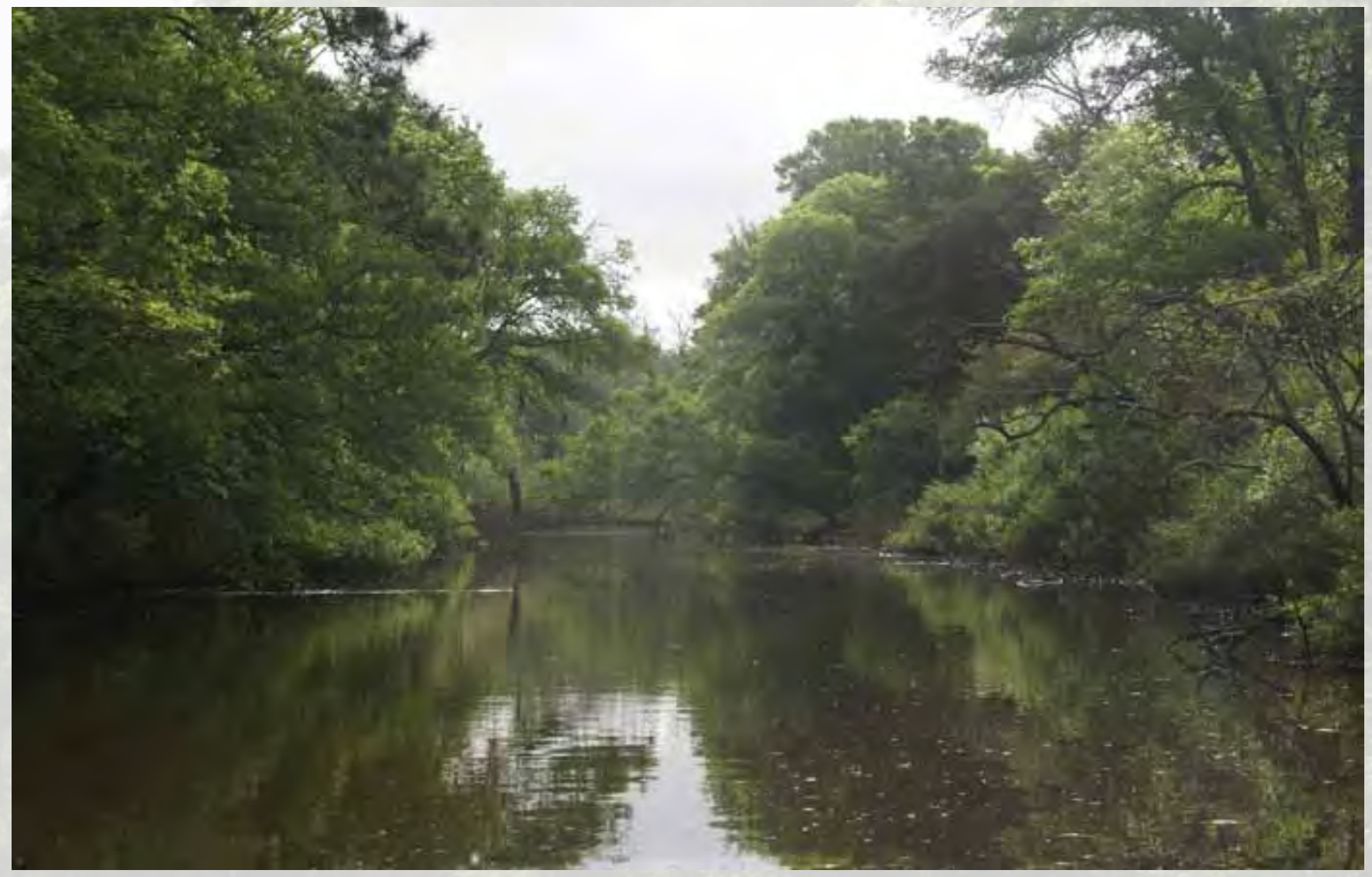

Data Series 407 
Cover: Cotton Bayou near Cotton Lake, Texas, August 2006 (photograph by Patrick O. Keefe, U.S. Geological Survey). 


\section{Water-Quality, Stream-Habitat, and Biological Data for West Fork Double Bayou, Cotton Bayou, and Hackberry Gully, Chambers County, Texas, 2006-07}

By Dexter W. Brown and Michael J. Turco

In cooperation with the Houston-Galveston Area Council and Texas Commission on Environmental Quality

Data Series 407 


\section{U.S. Department of the Interior \\ KEN SALAZAR, Secretary}

\section{U.S. Geological Survey Suzette M. Kimball, Acting Director}

U.S. Geological Survey, Reston, Virginia: 2009 This and other USGS information products are available at http://store.usgs.gov/
U.S. Geological Survey
Box 25286 , Denver Federal Center
Denver, CO 80225
To learn about the USGS and its information products visit http://www.usgs.gov/
1-888-ASK-USGS

Any use of trade, product, or firm names is for descriptive purposes only and does not imply endorsement by the U.S. Government.

Although this report is in the public domain, permission must be secured from the individual copyright owners to reproduce any copyrighted materials contained within this report.

Suggested citation:

Brown, D.W., and Turco, M.J., 2009, Water-quality, stream-habitat, and biological data for West Fork Double Bayou, Cotton Bayou, and Hackberry Gully, Chambers County, Texas, 2006-07: U.S. Geological Survey Data Series 407, 36 p. 


\section{Contents}

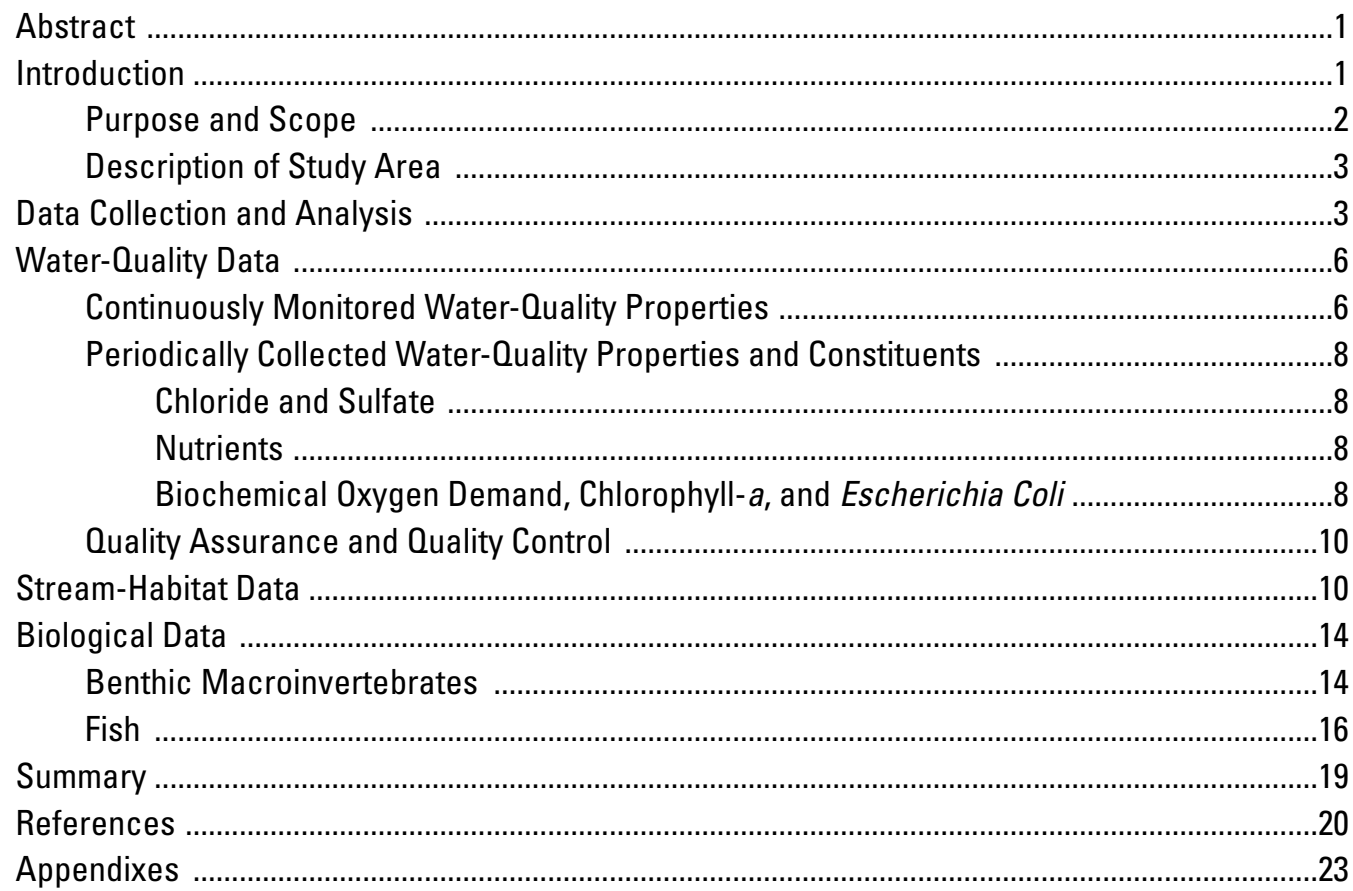

\section{Figures}

1-2. Maps showing:

1. West Fork Double Bayou, Cotton Bayou, and Hackberry Gully watersheds and locations of sampling sites (reaches), Chambers County, Texas, 2006-07

2. Land-cover distribution in the West Fork Double Bayou, Cotton Bayou, and Hackberry Gully watersheds, Chambers County, Texas

3-10. Graphs showing:

3. Rainfall at National Weather Service station Anahuac (COOP ID 410235),

Chambers County, Texas, July 2006-August 2007

4. Continuous dissolved oxygen at sites (reaches) (A) 08067244 Hackberry Gully at FM 3180 near Cove, Texas, and (B) 08067248 Cotton Bayou near Cotton Lake near Cove, Texas, July 13-17, 2006

5. Distribution by site of $(A)$ chloride and $(B)$ sulfate in samples from three sites (reaches), Cotton Bayou (08067239, 08067248) and Hackberry Gully (08067244), Chambers County, Texas, 2006-07

6. Distribution by site of $(A)$ ammonia plus organic nitrogen, $(B)$ ammonia nitrogen, (C) nitrate plus nitrite nitrogen, (D) nitrite nitrogen, (E) orthophosphate phosphorus, and (F) total phosphorus in samples from three sites (reaches), Cotton Bayou (08067239, 08067248) and Hackberry Gully (08067244), Chambers County, Texas, 2006-07

7. Distribution by site of (A) biochemical oxygen demand, (B) chlorophyll-a, and (C) Escherichia coli in samples from three sites (reaches), Cotton Bayou (08067239, 08067248) and Hackberry Gully (08067244), Chambers County, Texas, 2006-07 
8. Relative abundance of benthic macroinvertebrates for representative reach at each of four sites, West Fork Double Bayou (08042550, 08042554), Cotton Bayou (08067239), and Hackberry Gully (08067244), Chambers County, Texas, 2006-07

9. Relative abundance of fish functional feeding groups for representative reach at each of four sites, West Fork Double Bayou (08042550, 08042554), Cotton Bayou (08067239), and Hackberry Gully (08067244), Chambers County, Texas, 2006-07

10. Number of fish collected relative to number of fish species from representative reach at each of four sites, West Fork Double Bayou (08042550, 08042554), Cotton Bayou (08067239), and Hackberry Gully (08067244), Chambers County, Texas, 2006-07 .18

\section{Tables}

1. Data-collection sites (reaches) and types of data collected at each, West Fork Double Bayou, Cotton Bayou, and Hackberry Gully, Chambers County, Texas, 2006-07

2. Summary of 24-hour water temperature data collected at five sites (reaches), West Fork Double Bayou (08042550, 08042554), Cotton Bayou (08067239, 08067248), and Hackberry Gully (08067244), Chambers County, Texas, 2006-07

3. Summary of 24-hour pH data collected at five sites (reaches), West Fork Double Bayou (08042550, 08042554), Cotton Bayou (08067239, 08067248), and Hackberry Gully (08067244), Chambers County, Texas, 2006-07

4. Summary of 24-hour specific conductance data collected at five sites (reaches), West Fork Double Bayou (08042550, 08042554), Cotton Bayou (08067239, 08067248), and Hackberry Gully (08067244), Chambers County, Texas, 2006-07

5. Summary of 24-hour dissolved oxygen data collected at five sites (reaches), West Fork Double Bayou (08042550, 08042554), Cotton Bayou (08067239, 08067248), and Hackberry Gully (08067244), Chambers County, Texas, 2006-07

6. Scores for stream-habitat metrics and habitat quality index for representative reach at each of four sites, West Fork Double Bayou (08042550, 08042554), Cotton Bayou (08067239), and Hackberry Gully (08067244), Chambers County, Texas, 2006-07

7. Scores for benthic macroinvertebrate metrics and aquatic life use for representative reach at each of four sites, West Fork Double Bayou (08042550, 08042554), Cotton Bayou (08067239), and Hackberry Gully (08067244), Chambers County, Texas, 2006-07

8. Scores for fish metrics and index of biotic integrity for representative reach at each of four sites, West Fork Double Bayou (08042550, 08042554), Cotton Bayou (08067239), and Hackberry Gully (08067244), Chambers County, Texas, 2006-07

9. Average aquatic-life-use indicated by stream habitat, benthic macroinvertebrates, and fish for representative reach at each of four sites, West Fork Double Bayou (08042550, 08042554), Cotton Bayou (08067239), and Hackberry Gully (08067244), Chambers County, Texas, 2006-07

\section{Datums}

Vertical coordinate information is referenced to North American Vertical Datum of 1988 (NAVD 88).

Horizontal coordinate information is referenced to North American Datum of 1983 (NAD 83). 


\title{
Water-Quality, Stream-Habitat, and Biological Data for West Fork Double Bayou, Cotton Bayou, and Hackberry Gully, Chambers County, Texas, 2006-07
}

\author{
By Dexter W. Brown and Michael J. Turco
}

\section{Abstract}

The U.S. Geological Survey (USGS), in cooperation with the Houston-Galveston Area Council and the Texas Commission on Environmental Quality, collected waterquality, stream-habitat, and biological data from two sites at West Fork Double Bayou, two sites at Cotton Bayou, and one site at Hackberry Gully in Chambers County, Texas, during July 2006-August 2007. Water-quality data-collection surveys consisted of synoptic 24-hour continuous measurements of water temperature, $\mathrm{pH}$, specific conductance, and dissolved oxygen at the five sites and periodically collected samples at four sites analyzed for several properties and constituents of interest. Stream-habitat data were collected at each of four sites three times during the study. At each site, a representative stream reach was selected and within this reach, five evenly spaced stream transects were determined. At each transect, stream attributes (wetted channel width, water depth, bottom material, instream cover) and riparian attributes (bank slope and erosion potential, width of natural vegetation, type of vegetation, percentage tree canopy) were measured.

Benthic macroinvertebrate and fish data were collected from the same reaches identified for habitat evaluation. A total of 2,572 macroinvertebrate individuals were identified from the four reaches; insect taxa were more abundant than non-insect taxa at all reaches. A total of 1,082 fish, representing 30 species and 13 families, were collected across all reaches. Stream-habitat and aquatic biota (benthic macroinvertebrates and fish) were assessed at the four sites to evaluate aquatic life use. Habitat quality index scores generally indicated "intermediate" aquatic life use at most reaches. Benthic macroinvertebrate metrics scores indicated generally "intermediate" aquatic life use for the West Fork Double Bayou reaches and generally "high" aquatic life use for the Cotton Bayou and Hackberry Gully reaches. Index of biotic integrity scores for fish indicated generally "high" aquatic life use at one West Fork Double Bayou reach; "intermediate" aquatic life use at the other West Fork Double Bayou reach; and generally "intermediate" aquatic life use at the Cotton Bayou and Hackberry Gully reaches.

\section{Introduction}

The Texas Commission on Environmental Quality (TCEQ) administers water-quality management programs with the goal of protecting, maintaining, and restoring water resources in Texas. One program is the Texas Clean Rivers Program (CRP), which was established by the 1991 Texas Legislature (Texas Administrative Code, 2007). Under the CRP, water-quality monitoring and assessments are conducted in 23 river and coastal basins statewide through contracts with partner agencies. The Houston-Galveston Area Council (H-GAC) is the partner agency for a 13-county service area in southeastern Texas that includes the Houston metropolitan area. Every 2 years (biennium), CRP partners may perform systematic monitoring studies, whereby a variety of data are collected in water bodies that are not monitored routinely. Data from these special studies help to determine whether additional assessment is needed to evaluate human health concerns, the status of ecological conditions, or designated stream uses.

West Fork Double Bayou, Cotton Bayou, and Hackberry Gully in Chambers County (fig. 1) were chosen for this monitoring study. West Fork Double Bayou enters Trinity Bay from the east. A tributary entering the bayou contains outflow from the city of Anahuac; from there, the bayou meanders southward to the community of Oak Island and thence to Trinity Bay. Hackberry Gully enters Cotton Bayou in the Cotton Bayou watershed in western Chambers County. Currently (2008), Mont Belvieu is the major urbanized community in the Cotton Bayou watershed; however, the entire area is beginning to experience urban sprawl. West Fork Double Bayou and Cotton Bayou currently (2008) are listed on the 303(d) list of impaired waters in Texas for low dissolved oxygen (Texas Commission on Environmental Quality, 2008).

To better understand the spatial and temporal variability of water quality in the three water bodies and to characterize the habitat of the water bodies and the status of their biological communities, the U.S. Geological Survey (USGS), in cooperation with H-GAC and TCEQ, collected data during 2006-07 to document water-quality, stream-habitat, and biological 


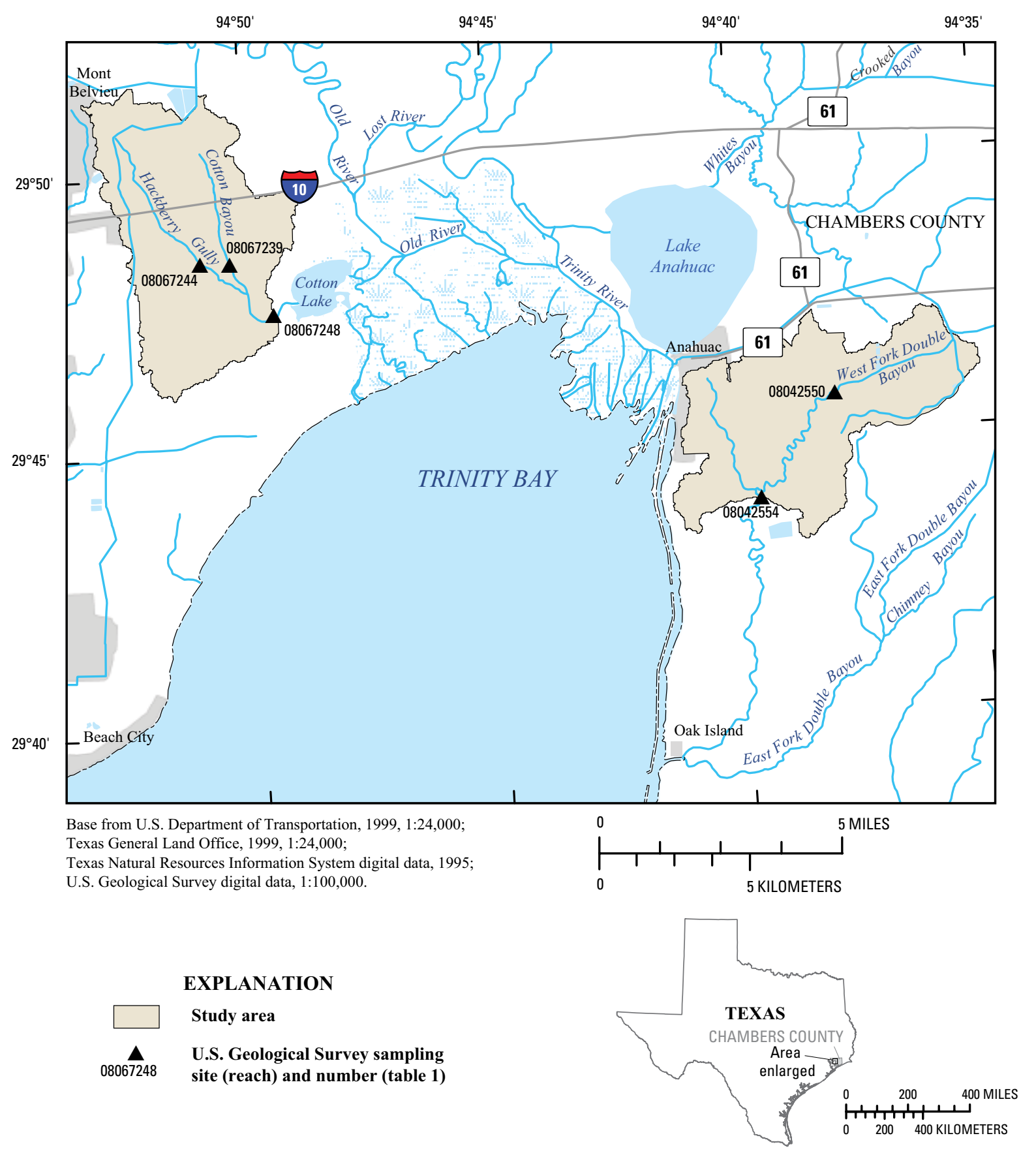

Figure 1. West Fork Double Bayou, Cotton Bayou, and Hackberry Gully watersheds and locations of sampling sites (reaches), Chambers County, Texas, 2006-07.

conditions in West Fork Double Bayou, Cotton Bayou, and Hackberry Gully (table 1).

\section{Purpose and Scope}

The purpose of this report is to document the water-quality, stream-habitat, and biological data collected from five sites (reaches) on West Fork Double Bayou, Cotton
Bayou, and Hackberry Gully during July 2006-August 2007. Data-collection methods are described, and data are presented to compare water-quality changes at and among sites during the study period. In addition, water-quality data were compared to State screening thresholds for selected water-quality constituents. Metrics computed from stream-habitat and biological data were compared to State indexes for aquatic life use (Texas Commission on Environmental Quality, 2007). 
Table 1. Data-collection sites (reaches) and types of data collected at each, West Fork Double Bayou, Cotton Bayou, and Hackberry Gully, Chambers County, Texas, 2006-07.

[USGS, U.S. Geological Survey; TCEQ, Texas Commission on Environmental Quality; WWTP, wastewater treatment plant]

\begin{tabular}{|c|c|c|c|c|c|c|c|c|c|c|c|c|}
\hline \multirow[b]{2}{*}{$\begin{array}{c}\text { USGS site } \\
\text { (reach) } \\
\text { number } \\
\text { (fig. 1) }\end{array}$} & \multirow[b]{2}{*}{$\begin{array}{c}\text { TCEO } \\
\text { site } \\
\text { (reach) } \\
\text { number }\end{array}$} & \multirow[b]{2}{*}{$\begin{array}{l}\text { USGS site } \\
\text { (reach) name }\end{array}$} & \multirow[b]{2}{*}{$\begin{array}{l}\text { Latitude }^{1} \\
\text { (decimal } \\
\text { degrees) }\end{array}$} & \multirow[b]{2}{*}{$\begin{array}{c}\text { Longitude } \\
\text { (decimal } \\
\text { degrees) }\end{array}$} & \multirow[b]{2}{*}{$\begin{array}{l}\text { Drain- } \\
\text { age } \\
\text { area } \\
\text { (square } \\
\text { miles) }\end{array}$} & \multirow[b]{2}{*}{$\begin{array}{c}\text { Altitude } \\
\text { (feet } \\
\text { above } \\
\text { NAVD 88) }\end{array}$} & \multicolumn{6}{|c|}{ Data collected } \\
\hline & & & & & & & $\begin{array}{c}\text { Con- } \\
\text { tinuous } \\
\text { proper- } \\
\text { ties }^{2}\end{array}$ & $\begin{array}{l}\text { Periodic } \\
\text { proper- } \\
\text { ties and } \\
\text { constitu- } \\
\text { ents }^{3}\end{array}$ & $\begin{array}{l}\text { Bac- } \\
\text { teria }\end{array}$ & $\begin{array}{l}\text { Stream } \\
\text { habitat }\end{array}$ & $\begin{array}{c}\text { Benthic } \\
\text { macro- } \\
\text { inverte- } \\
\text { brates }\end{array}$ & Fish \\
\hline 08042550 & 20016 & $\begin{array}{c}\text { West Fork Double Bayou } \\
\text { near Anahuac, Tex. }\end{array}$ & 29.761 & 94.633 & 6.25 & 10.00 & $\bullet$ & & & $\bullet$ & $\cdot$ & $\cdot$ \\
\hline 08067239 & 20003 & $\begin{array}{l}\text { Cotton Bayou upstream } \\
\text { of WWTP } 11449 \text { near } \\
\text { Cove, Tex. }\end{array}$ & 29.807 & 94.839 & 5.14 & 8.00 & $\bullet$ & $\bullet$ & $\bullet$ & $\bullet$ & - & $\bullet$ \\
\hline 08067244 & 20002 & $\begin{array}{l}\text { Hackberry Gully at FM } \\
3180 \text { near Cove, Tex. }\end{array}$ & 29.808 & 94.849 & 5.32 & 10.00 & $\bullet$ & $\bullet$ & $\bullet$ & $\bullet$ & $\bullet$ & - \\
\hline
\end{tabular}

${ }^{1}$ Referenced to NAD 83.

${ }^{2}$ Water temperature, $\mathrm{pH}$, specific conductance, and dissolved oxygen.

${ }^{3}$ Water temperature, $\mathrm{pH}$, specific conductance, dissolved oxygen, transparency, turbidity, chloride, sulfate, residue, nutrients, organic carbon, biochemical oxygen demand, phytoplankton, and suspended sediment.

\section{Description of Study Area}

The West Fork Double Bayou watershed is in eastern Chambers County near the city of Anahuac (fig. 1) and has a drainage area of about 35 square miles. From its headwaters east of Anahuac, West Fork Double Bayou flows about 14 miles to the southwest into Trinity Bay. The watershed is largely nonurbanized (fig. 2) and consists of mostly unused land (grassland, woody land) and agricultural fields (cultivated land). Runoff from nonurbanized areas, small municipalities, and municipal wastewater treatment plants provide input to the bayou.

The Cotton Bayou watershed is in western Chambers County near Mont Belvieu (fig. 1) and has a drainage area of 16.5 square miles. From its headwaters north of Mont Belvieu, Cotton Bayou flows about 7 miles to the southeast into Cotton Lake, which empties into Trinity Bay (segment 2422). The Cotton Bayou watershed is largely nonurbanized (fig. 2) and consists of unused land (grassland, woody land) and agricultural fields (cultivated land). Runoff from nonurbanized areas, small municipalities, and municipal wastewater treatment plants provide input to Cotton Bayou. The principal tributary to Cotton Bayou is Hackberry Gully, which has similar land use and inputs. TCEQ had designated Cotton Bayou as impaired because of low dissolved oxygen; however, the previous assessment was based on only one set of samples and those measurements were collected in the tidal part of the bayou. The extent and validity of the impaired status is questionable because the freshwater part of the water body was not monitored.

Climatic conditions in the study area are classified as humid subtropical (Larkin and Bomar, 1983) and characterized by cool temperate winters, long hot summers, high relative humidity, and prevailing winds from the south and southeast. During the study, temperatures measured in Anahuac, Tex. (COOPID 410235), ranged from a mean of about 54 degrees Fahrenheit $\left({ }^{\circ} \mathrm{F}\right)$ in the winter (December-February) to a mean of about $81^{\circ} \mathrm{F}$ in the summer (June-August), with maximum temperatures higher than $90^{\circ} \mathrm{F}$ during about 10 percent of the study period (National Climatic Data Center, 2006-07). During the study, total rainfall was 99.72 inches (National Climatic Data Center, 2006-07); 10.71 inches of this amount occurred in July 2007 (fig. 3).

\section{Data Collection and Analysis}

Data for this report were collected from five sites (reaches) in West Fork Double Bayou (USGS sites 08042550, 08042554), Cotton Bayou (USGS sites 08067239, 08067248), and Hackberry Gully (USGS site 08067244) (fig. 1). Waterquality data are categorized by the way they were collected: (1) continuously monitored data—water-quality properties measured with a multiprobe instrument at each site; and 


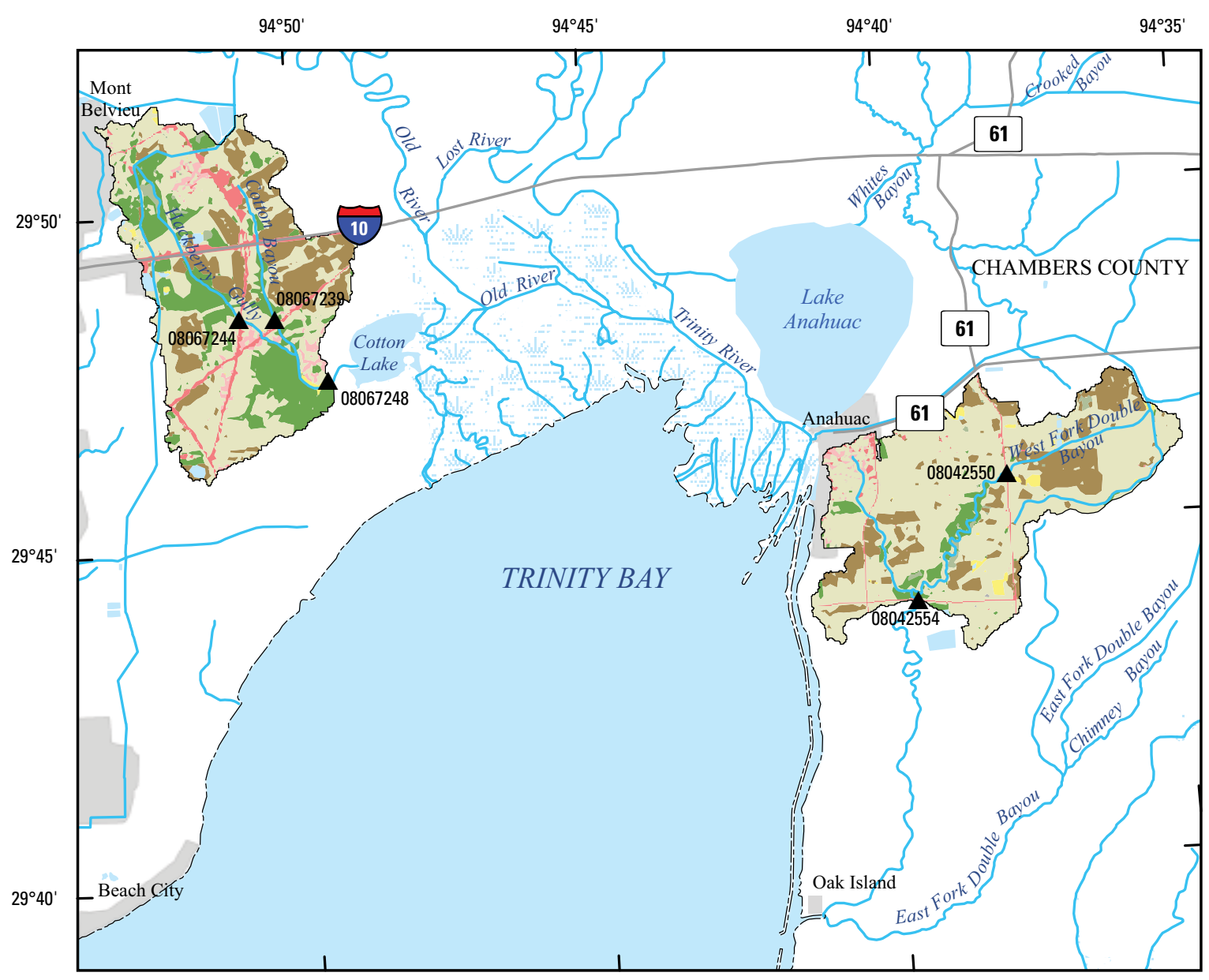

Base from U.S. Department of Transportation, 1999, 1:24,000; Texas General Land Office, 1999, 1:24,000;

Texas Natural Resources Information System digital data, 1995; U.S. Geological Survey digital data, 1:100,000.

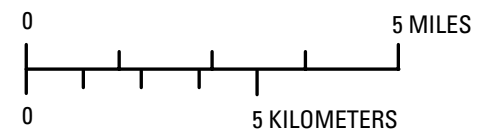

\section{EXPLANATION}

Study area land cover

Low intensity developed

High intensity developed

Cultivated land

Grassland

Woody land

Open water

Palustrine woody wetland

Palustrine emergent wetland

Bare/transitional

U.S. Geological Survey sampling site (reach) and number (table 1)

Figure 2. Land-cover distribution in the West Fork Double Bayou, Cotton Bayou, and Hackberry Gully watersheds, Chambers County, Texas.

(2) periodically collected data—water-quality properties and constituent concentrations obtained from analysis of discrete samples collected periodically at the sites.

Four properties (water temperature, $\mathrm{pH}$, specific conductance, and dissolved oxygen) were monitored continuously at the five sites (table 1) for periods ranging from 24 hours to several days during July, August, and October 2006, and
March, May, June, and August 2007. At each site, monitors were located where depth and flow conditions were typical of the reach used for biological data collection. Properties were measured and logged by the monitors at 15-minute intervals.

The same four properties plus transparency and turbidity were measured and the constituents listed below were sampled six times during July 2006-August 2007 at the two Cotton 


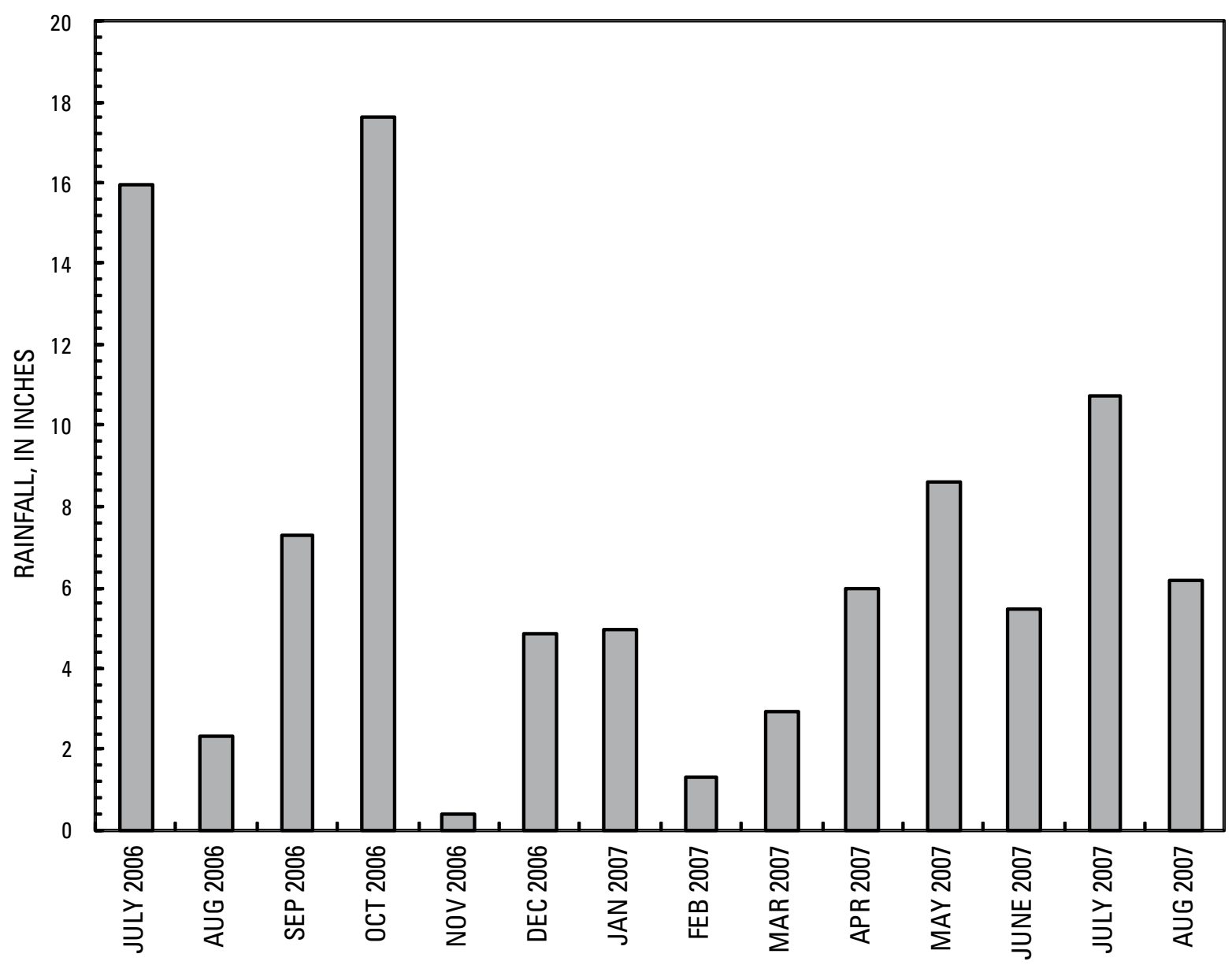

Figure 3. Rainfall at National Weather Service station Anahuac (COOP ID 410235), Chambers County, Texas, July 2006-August 2007.

Bayou sites (08067239, 08067248) and the Hackberry Gully site (08067244) (table 1):

1. Chloride and sulfate

2. Residue on evaporation and total residue

3. Nutrients (ammonia plus organic nitrogen, ammonia nitrogen, nitrate plus nitrite nitrogen, nitrite nitrogen, orthophosphate phosphorus, total phosphorus)

4. Total organic carbon

5. Biochemical oxygen demand (BOD) and carbonaceous biochemical oxygen demand (CBOD)

6. Phytoplankton (chlorophyll- $a$, pheophytin- $a$ )

7. Suspended sediment

In addition, the fecal indicator bacteria Escherichia (E.) coli and total coliform (table 1) were analyzed in the six samples at one Cotton Bayou site (08067239) and the Hackberry Gully site (08067244); bacteria were analyzed in only one sample at the other Cotton Bayou site (08067248).
Before sample collection, properties were measured at three sections in the stream to determine uniformity of physical conditions across the channel. Water (grab) samples were collected at the center of the stream using methods described by the Texas Natural Resource Conservation Commission (1999). All samples were maintained at less than 4 degrees Celsius $\left({ }^{\circ} \mathrm{C}\right)$ until analysis. Analyses for most constituents were done at the USGS National Water Quality Laboratory (NWQL) in Denver, Colo., using methods described in Wershaw and others (1987), Fishman and Friedman (1989), Patton and Truitt (1992, 2000), Fishman (1993), and U.S. Environmental Protection Agency (1993). Analyses for BOD, CBOD (Delzer and McKenzie, 2003), and fecal indicator bacteria (Myers and others, 2007) were done at the USGS Texas Water Science Center Gulf Coast Program office. Suspended sediment concentrations were analyzed (Guy, 1969) at the USGS Louisiana Water Science Center Sediment Laboratory.

Stream-habitat data were collected at the two West Fork Double Bayou sites (08042550, 08042554), one Cotton Bayou site (08067239) and the Hackberry Gully site (08067244) three times during the study, in July-August 2006, March 2007, and July-August 2007. At each site, a representative 
stream reach was selected (Texas Commission on Environmental Quality, 2007). Within each reach, five evenly spaced stream transects were determined. At each transect, stream attributes (wetted channel width, water depth, bottom material, instream cover) and riparian attributes (bank slope and erosion potential, width of natural vegetation, type of vegetation, percentage tree canopy) were categorized or measured. The number of stream bends and riffles and the overall aesthetic condition were determined. The dominant substrates were noted at all sites. A habitat quality index was calculated for stream-habitat data at each site to indicate aquatic-life-use scores described by the Texas Commission on Environmental Quality (2007).

Benthic macroinvertebrates were sampled at a representative reach of the same four sites (table 1) as for habitat data using TCEQ Rapid Bioassessment Protocols (RBPs) for sampling woody debris (snag) habitat in soft bottom streams (Texas Commission on Environmental Quality, 2007). About 10 well-conditioned snags were collected at each reach using lopping shears and a D-frame net with 500-micrometer mesh. Snags were collected from sections of the reach with good water flow when possible. Benthic macroinvertebrates were removed from the snags by washing with a squirt bottle into a 0.05 -centimeter mesh sieve. Snags were then carefully inspected and any remaining benthic macroinvertebrates were removed with forceps and added to the sieve. Samples were then processed in accordance with RBPs (Texas Commission on Environmental Quality, 2007). The contents of the washing sieve were placed in a sorting tray, random subsamples were removed, and all benthic macroinvertebrates in each subsample were collected and placed in a 1-liter polyethylene bottle. Subsamples were removed until a minimum of 140 individual benthic macroinvertebrates were counted. Processed benthic macroinvertebrate samples were preserved in 80-percent ethanol and submitted to EcoAnalysts, Inc., in Moscow, Idaho, for taxonomic identification and enumeration. All benthic macroinvertebrates collected were identified to the lowest taxonomic level possible. A reference collection, with at least one specimen of each taxon identified was provided to the USGS by EcoAnalysts, Inc.

A tolerance value and functional feeding group designation were assigned to each benthic macroinvertebrate taxa as defined by TCEQ classification guidance (Texas Natural Resource Conservation Commission, 1999). Each macroinvertebrate community was assessed on the basis of metrics described in "Surface Water Quality Monitoring Procedures, Volume 2" (Texas Commission on Environmental Quality, 2007).

As part of the initial biological sampling (July 2006), the benthic macroinvertebrate sample from one site was split to create a primary sample and a replicate sample. This was done by dividing the sample into subsections and identifying and enumerating all individuals in each subsection until a minimum of 100 individuals was obtained (Texas Natural Resource Conservation Commission, 1999).
Fish sampling (surveys) were done at a representative reach of the same four sites (table 1) where habitat data were collected. Fish were collected using a combination of seining and electrofishing methods (Texas Commission on Environmental Quality, 2007). Seining, or seine netting, involves manually pulling a large, mesh net through relatively shallow water nearshore. Seine netting was done with a 15-foot flat-panel seine with a 0.64-centimeter mesh. Electrofishing involves the application of electrical current to the water to stun fish. Electrofishing was done with a Smith-Root 5.0 Generator Powered Pulsator electrofishing system with a maximum power output of 5,000 watts. The electrofishing system was deployed from a barge wading unit in all reaches except at site 08042554 , where the unit was deployed from a boat because of deep water. Electrofishing at each site was done over the entire reach for a minimum of 900 seconds ( 15 minutes) and included all habitat types. Stunned fish were collected with a net and placed in an aerated holding tank for recovery and transport to the processing station for identification. Captured fish were identified to the lowest taxonomic category possible (generally species). After collection and identification at the stream, fish were released.

Seining was used to supplement electrofishing efforts at all reaches except site 08042554, where deep water and abundant snags prevented effective seine netting. Fish collected by seining were kept separate from fish collected by electrofishing for identification and enumeration so that the effectiveness of each method could be assessed.

Individuals of unknown species were preserved in 10percent buffered formalin and sent to Dr. Dean Hendrickson, ichthyologist, at the Texas Memorial Museum at The University of Texas, Austin, for final identification and storage. Voucher specimens (specimens retained for reference) were collected for all taxa at each reach. Small taxa were vouchered by preserving a representative specimen in 10-percent buffered formalin, and large taxa were vouchered by photographing a representative specimen.

A tolerance rating and trophic group were assigned to each species (Linam and Kleinsasser, 1998). An index of biotic integrity was calculated for the combined catch for each site using scoring indexes developed to assess stream fish assemblages in the Western Gulf Coastal Plain (ecoregion 34) (Linam and others, 2002).

\section{Water-Quality Data}

\section{Continuously Monitored Water-Quality Properties}

Measured water temperatures (table 2) ranged from a minimum of $19.3{ }^{\circ} \mathrm{C}$ in March 2007 at 08067239 to a maximum of $32.5^{\circ} \mathrm{C}$ in August 2006 at site 08042554 . Median $\mathrm{pH}$ (table 3 ) for all sites varied from 6.4 to 8.4. The maximum $\mathrm{pH}$ 
Table 2. Summary of 24-hour water temperature data collected at five sites (reaches), West Fork Double Bayou (08042550, 08042554), Cotton Bayou (08067239, 08067248), and Hackberry Gully (08067244), Chambers County, Texas, 2006-07.

[USGS, U.S. Geological Survey; --, no data]

\begin{tabular}{|c|c|c|c|c|c|c|c|c|}
\hline \multirow{2}{*}{$\begin{array}{c}\text { USGS site } \\
\text { (reach) number } \\
\text { (fig. 1) }\end{array}$} & \multirow{2}{*}{ Statistic } & \multicolumn{7}{|c|}{$\begin{array}{l}\text { Measured water temperature } \\
\text { (degrees Celsius) }\end{array}$} \\
\hline & & $\begin{array}{l}\text { July } \\
2006\end{array}$ & $\begin{array}{c}\text { August } \\
2006\end{array}$ & $\begin{array}{l}\text { October } \\
2006\end{array}$ & $\begin{array}{l}\text { March } \\
2007\end{array}$ & $\begin{array}{l}\text { May } \\
2007\end{array}$ & $\begin{array}{l}\text { June } \\
2007\end{array}$ & $\begin{array}{c}\text { August } \\
2007\end{array}$ \\
\hline \multirow[t]{3}{*}{08042550} & Maximum & -- & -- & -- & -- & -- & -- & 30.7 \\
\hline & Minimum & -- & -- & -- & -- & -- & -- & 27.7 \\
\hline & Mean & -- & -- & -- & -- & -- & -- & 29.1 \\
\hline \multirow[t]{3}{*}{08042554} & Maximum & -- & 32.5 & -- & -- & -- & -- & 30.9 \\
\hline & Minimum & -- & 30.5 & -- & -- & -- & -- & 28.1 \\
\hline & Mean & -- & 31.2 & -- & -- & -- & -- & 29.5 \\
\hline \multirow[t]{3}{*}{08067239} & Maximum & 29.7 & -- & 25.6 & 23.2 & 26.8 & -- & 28.4 \\
\hline & Minimum & 27.4 & -- & 23.7 & 19.3 & 24.4 & -- & 27.2 \\
\hline & Mean & 28.5 & -- & 24.8 & 20.9 & 25.2 & -- & 27.8 \\
\hline \multirow[t]{3}{*}{08067244} & Maximum & 31.3 & -- & 24.1 & 23.5 & 25.6 & -- & 29.5 \\
\hline & Minimum & 28.4 & -- & 23.3 & 19.6 & 25.3 & -- & 28.7 \\
\hline & Mean & 29.6 & -- & 23.7 & 21.2 & 25.4 & -- & 29.0 \\
\hline \multirow[t]{3}{*}{08067248} & Maximum & 31.2 & 28.7 & -- & 24.9 & 26.4 & 29.8 & 31.7 \\
\hline & Minimum & 26.0 & 27.8 & -- & 20.3 & 25.6 & 26.8 & 30.9 \\
\hline & Mean & 29.4 & 28.2 & -- & 22.7 & 26.1 & 27.6 & 31.4 \\
\hline
\end{tabular}

Table 3. Summary of 24-hour pH data collected at five sites (reaches), West Fork Double Bayou (08042550, 08042554), Cotton Bayou (08067239, 08067248), and Hackberry Gully (08067244), Chambers County, Texas, 2006-07.

[USGS, U.S. Geological Survey; --, no data]

\begin{tabular}{|c|c|c|c|c|c|c|c|c|}
\hline \multirow{2}{*}{$\begin{array}{c}\text { USGS site } \\
\text { (reach) number } \\
\text { (fig. 1) }\end{array}$} & \multirow{2}{*}{ Statistic } & \multicolumn{7}{|c|}{$\begin{array}{l}\text { Measured pH } \\
\text { (standard units) }\end{array}$} \\
\hline & & $\begin{array}{l}\text { July } \\
2006\end{array}$ & $\begin{array}{l}\text { August } \\
2006\end{array}$ & $\begin{array}{l}\text { October } \\
2006\end{array}$ & $\begin{array}{l}\text { March } \\
2007\end{array}$ & $\begin{array}{l}\text { May } \\
2007\end{array}$ & $\begin{array}{l}\text { June } \\
2007\end{array}$ & $\begin{array}{c}\text { August } \\
2007\end{array}$ \\
\hline \multirow[t]{3}{*}{08042550} & Maximum & -- & -- & -- & -- & -- & -- & 7.1 \\
\hline & Minimum & -- & -- & -- & -- & -- & -- & 7.0 \\
\hline & Median & -- & -- & -- & -- & -- & -- & 7.0 \\
\hline \multirow[t]{3}{*}{08042554} & Maximum & -- & 6.5 & -- & -- & -- & -- & 7.8 \\
\hline & Minimum & -- & 6.4 & -- & -- & -- & -- & 6.7 \\
\hline & Median & -- & 6.4 & -- & -- & -- & -- & 7.1 \\
\hline \multirow[t]{3}{*}{08067239} & Maximum & 7.9 & -- & 7.8 & 8.0 & 7.8 & -- & 7.9 \\
\hline & Minimum & 7.8 & -- & 7.7 & 7.2 & 7.7 & -- & 7.6 \\
\hline & Median & 7.8 & -- & 7.8 & 7.6 & 7.7 & -- & 7.8 \\
\hline \multirow[t]{3}{*}{08067244} & Maximum & 7.4 & -- & 7.3 & 7.9 & 7.5 & -- & 7.5 \\
\hline & Minimum & 7.2 & -- & 7.2 & 7.1 & 7.4 & -- & 7.3 \\
\hline & Median & 7.3 & -- & 7.3 & 7.3 & 7.4 & -- & 7.4 \\
\hline \multirow[t]{3}{*}{08067248} & Maximum & 9.0 & 7.0 & -- & 7.9 & 7.4 & 7.7 & 7.6 \\
\hline & Minimum & 8.3 & 6.8 & -- & 7.3 & 6.7 & 7.5 & 7.4 \\
\hline & Median & 8.4 & 7.0 & -- & 7.5 & 6.9 & 7.7 & 7.5 \\
\hline
\end{tabular}


of 9.0 was measured at 08067248 in July 2006. The minimum pH was 6.4 at 08042554 in August 2006. Specific conductance (table 4) was generally lower at sites 08042550, 08042554, and 08067244 than at site 08067248 . For all sites, specific conductance ranged from 178 microsiemens per centimeter at $25{ }^{\circ} \mathrm{C}(\mu \mathrm{S} / \mathrm{cm})$ at 08042554 to $2,220 \mu \mathrm{S} / \mathrm{cm}$ at 08067248 . Because available specific conductance data reflect only small time periods, the true extent of tidal influence is not indicated by the data. However periodic water samples indicate tidal influence in accordance with criteria described by Texas Commission on Environmental Quality (2003a) at site 08067248 on October 3, 2006 (appendix 1). No sites where biological sampling took place were considered tidally influenced.

Dissolved oxygen is a primary component used to evaluate the suitability of a stream to sustain aquatic life. Fish that are intolerant of low levels of oxygen become stressed when concentrations of dissolved oxygen are less than about 5 milligrams per liter (mg/L). At levels below $2 \mathrm{mg} / \mathrm{L}$, fish kills can result (Fram, 2006). To maintain dissolved oxygen levels that will support fish, the Texas Commission on Environmental Quality (2003a) has established mean and minimum criteria for dissolved oxygen levels in natural waters, depending on the type of stream (freshwater or tidal). The 24-hour mean dissolved oxygen criterion for unclassified freshwater streams is $5.0 \mathrm{mg} / \mathrm{L}$ and for unclassified tidal streams is $4.0 \mathrm{mg} / \mathrm{L}$. The minimum criterion for both freshwater and tidal streams is 3.0 $\mathrm{mg} / \mathrm{L}$.

Continuously monitored mean dissolved oxygen (table 5) was less than the respective 24-hour mean dissolved oxygen criterion during at least one monitoring period at all sites. Minimum dissolved oxygen was less than the criterion during at least one monitoring period at all sites except for 08042550 and 08067239 . The lowest dissolved oxygen concentrations (mean of $1.5 \mathrm{mg} / \mathrm{L}$ ) were measured during August 2007 at 08067244. Graphs of dissolved oxygen concentration at sites 08067244 (fig. 4A) and 08067248 (fig. 4B) for July 12-17, 2006, show diurnal patterns and concentrations less than the minimum criterion $(3.0 \mathrm{mg} / \mathrm{L})$.

\section{Periodically Collected Water-Quality Properties and Constituents}

\section{Chloride and Sulfate}

Chloride and sulfate are not used as indicators for the suitability of streams for aquatic life use; they were established to ensure support of multiple uses and as tools to identify and manage the influences of point and nonpoint sources of pollution (Texas Commission on Environmental Quality, 2003a). The maximum chloride concentration (fig. 5A; appendix 1) was $4,190 \mathrm{mg} / \mathrm{L}$ at site 08067248 . The median chloride concentration from all sites was $87.1 \mathrm{mg} / \mathrm{L}$. The maximum sulfate concentration (fig. 5B; appendix 1) of $585 \mathrm{mg} / \mathrm{L}$ was measured at site 08067248 . The median sulfate concentration from all sites was $27.6 \mathrm{mg} / \mathrm{L}$.

\section{Nutrients}

Nitrogen compounds naturally occur in the environment, usually in small amounts in surface water, and include ammonia, organic nitrogen, nitrate, and nitrite. The largest ammonia plus organic nitrogen concentration $(1.2 \mathrm{mg} / \mathrm{L})$ was measured at sites 08067244 and 08067248 (fig. 6A; appendix 1), and the median for all samples was $0.79 \mathrm{mg} / \mathrm{L}$. The largest ammonia concentration was $0.12 \mathrm{mg} / \mathrm{L}$ at site 08067248 (fig. 6B; appendix 1), and the median for all samples was $0.05 \mathrm{mg} / \mathrm{L}$. Nitrate plus nitrite concentrations (fig. 6C; appendix 1) ranged from $0.010 \mathrm{mg} / \mathrm{L}$ (estimated) at site 08067244 to a maximum of $15.1 \mathrm{mg} / \mathrm{L}$ at site 08067239 ; the median for all samples was $0.316 \mathrm{mg} / \mathrm{L}$. Nitrite concentrations (fig. 6D; appendix 1) ranged from less than the laboratory reporting limit of 0.002 $\mathrm{mg} / \mathrm{L}$ at sites 08067244 and 08067248 to $0.066 \mathrm{mg} / \mathrm{L}$ at site 08067244; the median for all samples was $0.0095 \mathrm{mg} / \mathrm{L}$.

Orthophosphate is an inorganic form of phosphorus that is used by plants. It is produced by natural processes and also is found in sewage (Hem, 1985). Orthophosphate concentrations (fig. 6E; appendix 1) were largest at site 08067239 with a maximum of $2.96 \mathrm{mg} / \mathrm{L}$. The maximum concentration for the remaining sites was $0.453 \mathrm{mg} / \mathrm{L}$; the median orthophosphate concentration for all samples was $0.08 \mathrm{mg} / \mathrm{L}$. Total phosphorus includes dissolved forms as well as phosphorus attached to sediment particles and in living organisms like algae and bacteria. Total phosphorus concentrations (fig 6F; appendix 1) were largest at site 08067239 with a maximum of $3.01 \mathrm{mg} / \mathrm{L}$. The median from all samples was $0.215 \mathrm{mg} / \mathrm{L}$.

\section{Biochemical Oxygen Demand, Chlorophyll-a, and Escherichia Coli}

BOD is the measure of oxygen consumed by bacteria during decomposition of organic matter (Sawyer and McCarty, 1978). If the BOD of decomposition is large, dissolved oxygen concentrations can be close to zero. The largest measured BOD (4.5 mg/L) was at site 08067248 (fig. 7A; appendix 1). The median from all samples was $2.1 \mathrm{mg} / \mathrm{L}$.

Chlorophyll- $a$ is a photosynthetic pigment in algae and other green plants. The concentration of chlorophyll- $a$ is used to estimate the amount of phytoplankton in a water body (Porter and others, 1993). At sites 08067239 and 08067244 chlorophyll- $a$ concentrations (fig. 7B; appendix 1) were less than the applicable State screening level for tidal streams, 19.2 micrograms per liter $(\mu \mathrm{g} / \mathrm{L}$ ) (Texas Commission on Environmental Quality, 2003a, table 18). The maximum chlorophyll- $a$ concentration at site 08067248 was $36.7 \mu \mathrm{g} / \mathrm{L}$; the median concentration was $17.7 \mu \mathrm{g} / \mathrm{L}$. The median for all samples was $0.2 \mu \mathrm{g} / \mathrm{L}$.

E. coli is a fecal-indicator bacteria used to signal the potential presence in the water of harmful pathogens that come from warm-blooded animals. E. coli densities in three samples at site 08067239 (fig. 7C; appendix 2) exceeded 394 most probable number per 100 milliliters (MPN/100 mL), the State single-sample value for evaluating contact and non-contact 
A.

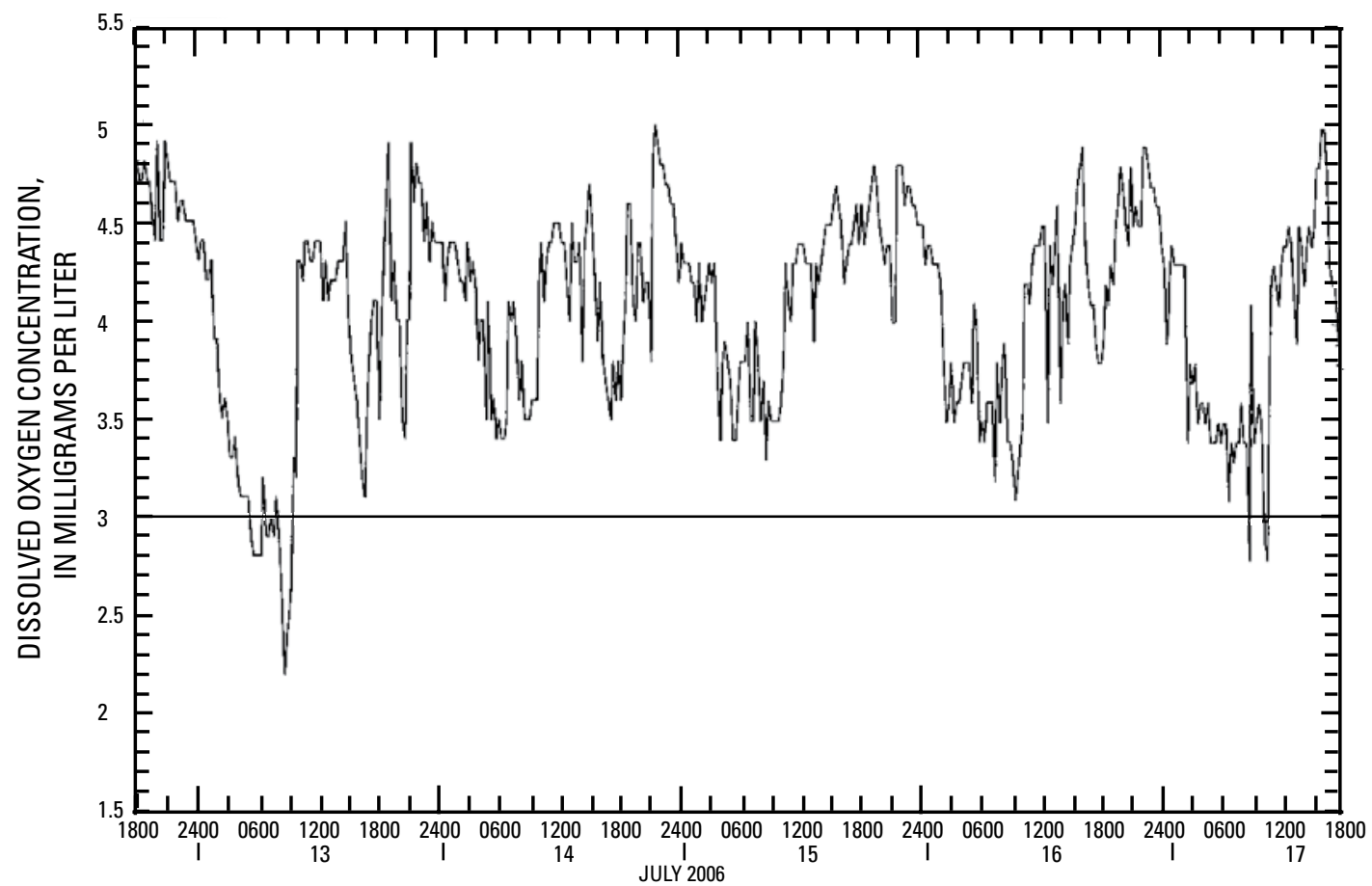

B.

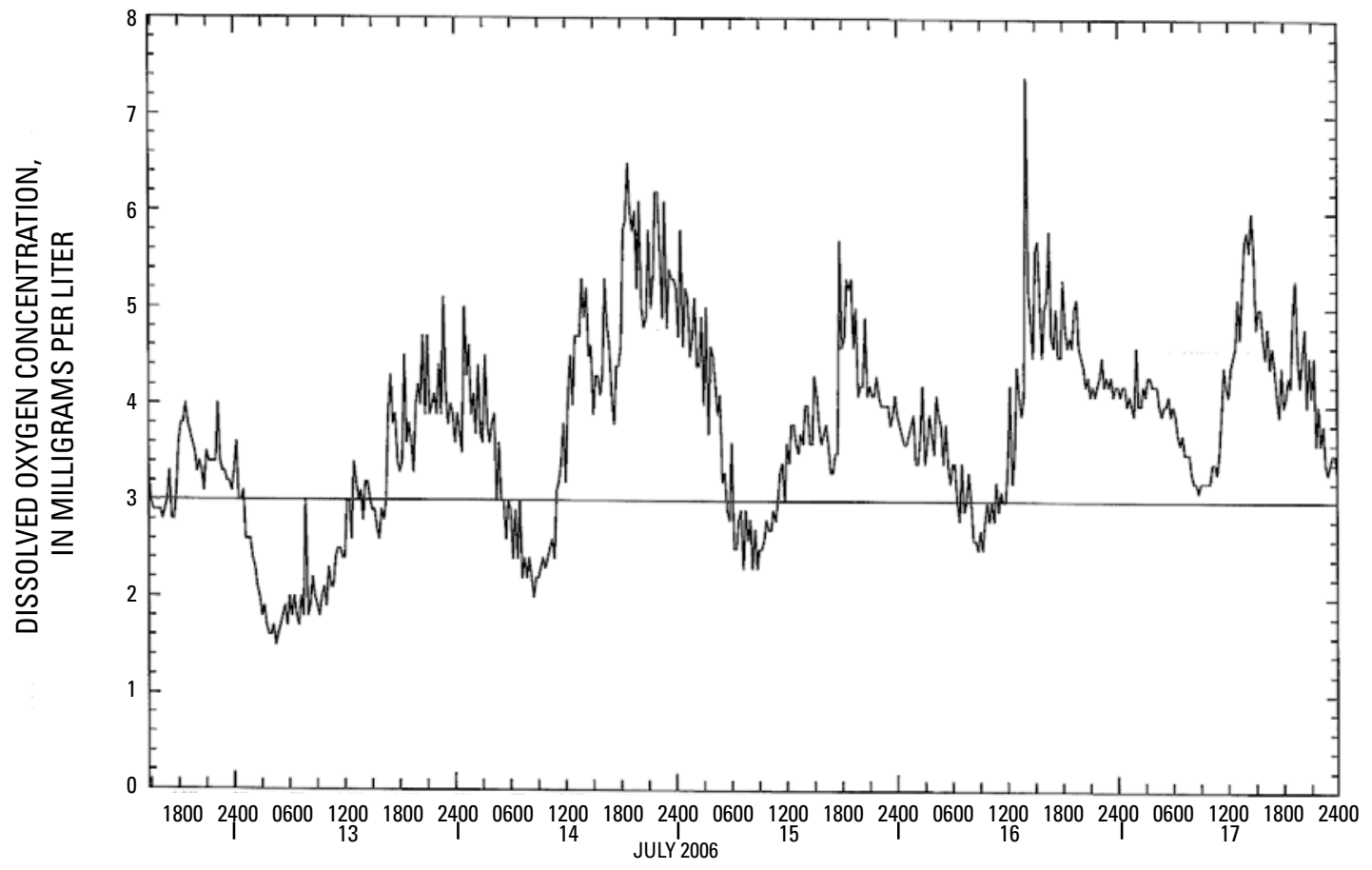

Figure 4. Continuous dissolved oxygen at sites (reaches) (A) 08067244 Hackberry Gully at FM 3180 near Cove, Texas, and (B) 08067248 Cotton Bayou near Cotton Lake near Cove, Texas, July 13-17, 2006. 
A.

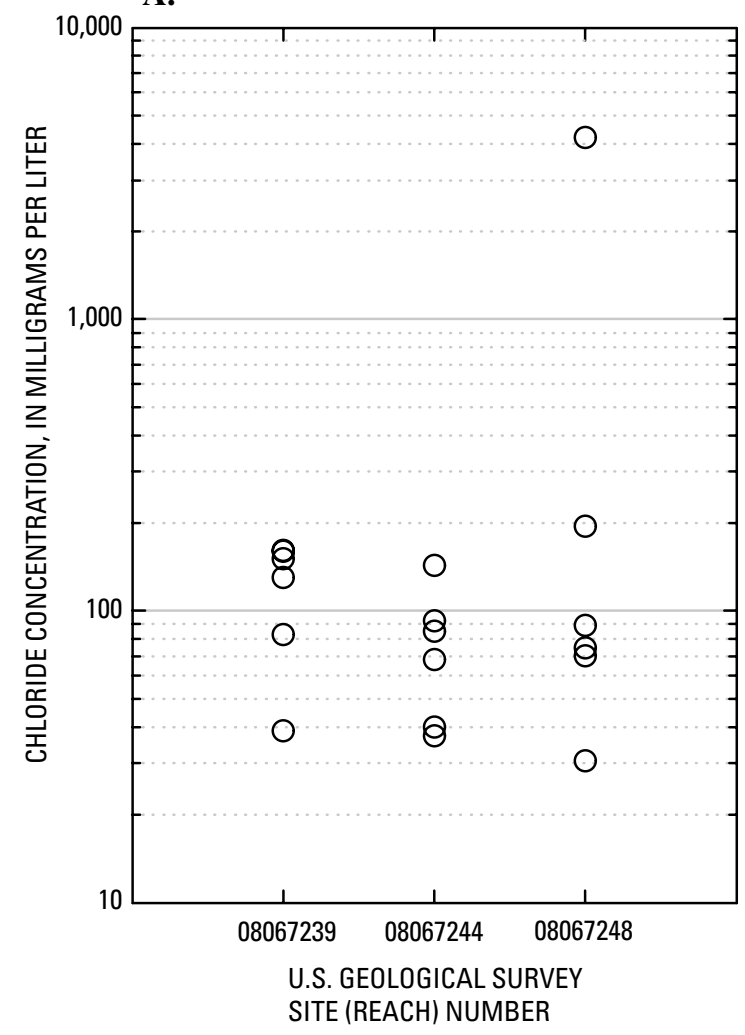

B.

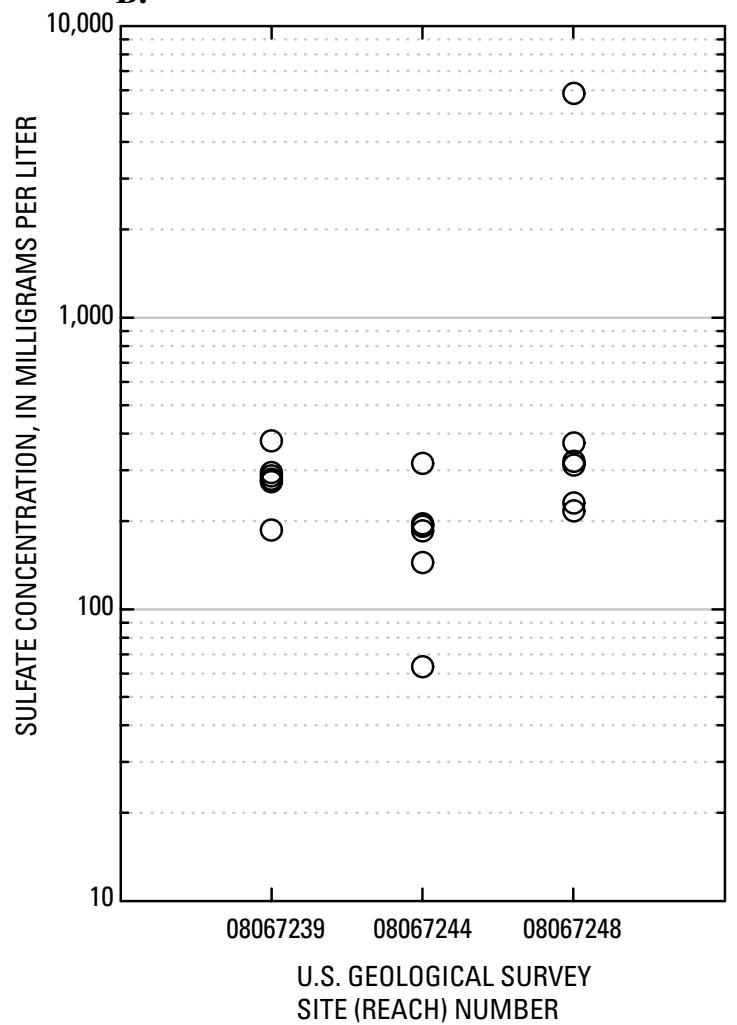

Figure 5. Distribution by site of (A) chloride and (B) sulfate in samples from three sites (reaches), Cotton Bayou $(08067239,08067248)$ and Hackberry Gully (08067244), Chambers County, Texas, 2006-07.

recreation use support (Texas Commission on Environmental Quality, 2003a, table 6). The largest density at site 08067239 was $690 \mathrm{MPN} / 100 \mathrm{~mL}$; the median density for all samples was $130 \mathrm{MPN} / 100 \mathrm{~mL}$.

\section{Quality Assurance and Quality Control}

All sample collection and processing, data management, and documentation followed guidelines of the Texas Natural Resource Conservation Commission (1999) and the Texas Commission on Environmental Quality (2003b). The guidelines are included in the Quality Assurance Project Plan (Jean Wright, Houston-Galveston Area Council, written commun., 2005).

Quality control (QC) samples (appendix 3) were used to evaluate the extent to which contamination, characteristics of the water (matrix), and measurement variability affected analytical results (Mueller and others, 1997). Further explanation of QC sample types and their use are described by Mueller and others (1997). Additional water was collected during the study to split into two samples; one was designated as the environmental sample and the other was a split replicate of that sample. Analytical results from each sample set were compared by computing the relative percentage difference (RPD) for each constituent. The RPD, specified for this project in the
Quality Assurance Project Plan as 20 percent, was calculated using the equation

$$
R P D=\left\{\left|\mathrm{S}_{1}-\mathrm{S}_{2}\right| /\left(\left[\mathrm{S}_{1}+\mathrm{S}_{2}\right] / 2\right)\right\} \times 100,
$$

where

$$
\begin{aligned}
& \mathrm{S}_{1}=\text { concentration from environmental sample; and } \\
& \mathrm{S}_{2}=\text { concentration from replicate sample. }
\end{aligned}
$$

The RPD exceeded 20 percent for five of the 20 constituents analyzed in the split sample collected at site 08067239 (appendix 3). Those constituents include total residue, BOD, CBOD, E. coli, and total coliform. The RPD exceeded 20 percent for the suspended sediment concentration in the split sample collected at 08067248 .

\section{Stream-Habitat Data}

The physical characteristics of a stream channel and the riparian characteristics can influence the structure and function of the benthic macroinvertebrate and fish communities (Stauffer and others, 2000; Brasher and others, 2003; Powers and others, 2003). Stream-habitat data were collected at the two West Fork Double Bayou reaches (08042550, 08042554), one Cotton Bayou reach (08067239), and Hackberry Gully 
A.

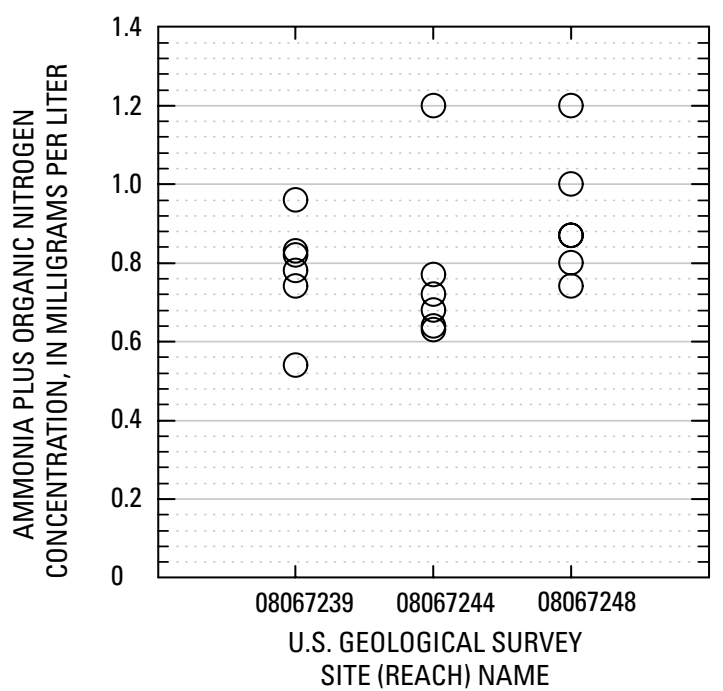

C.

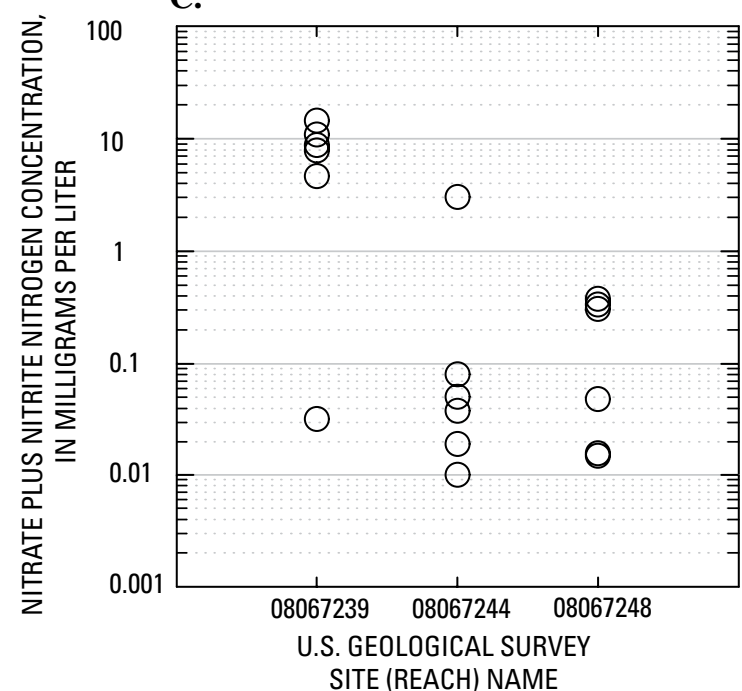

E.

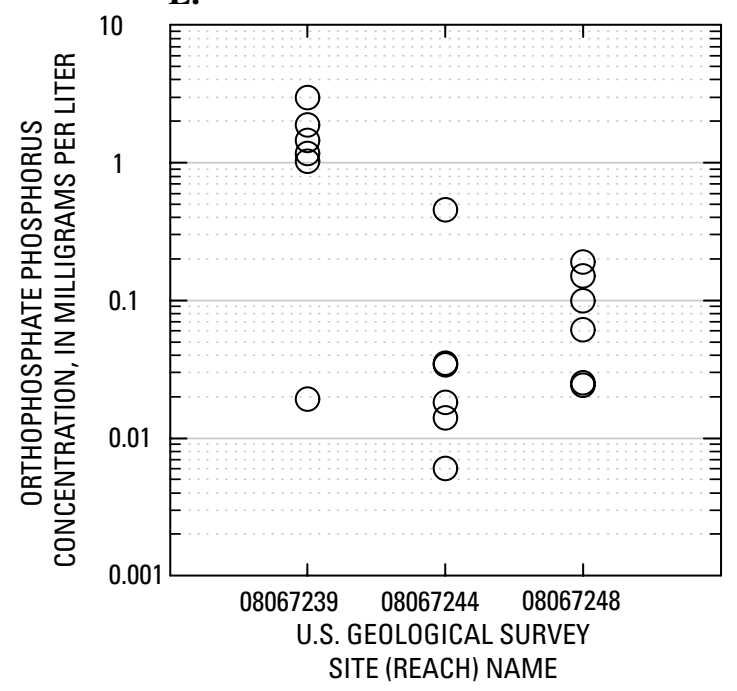

B.

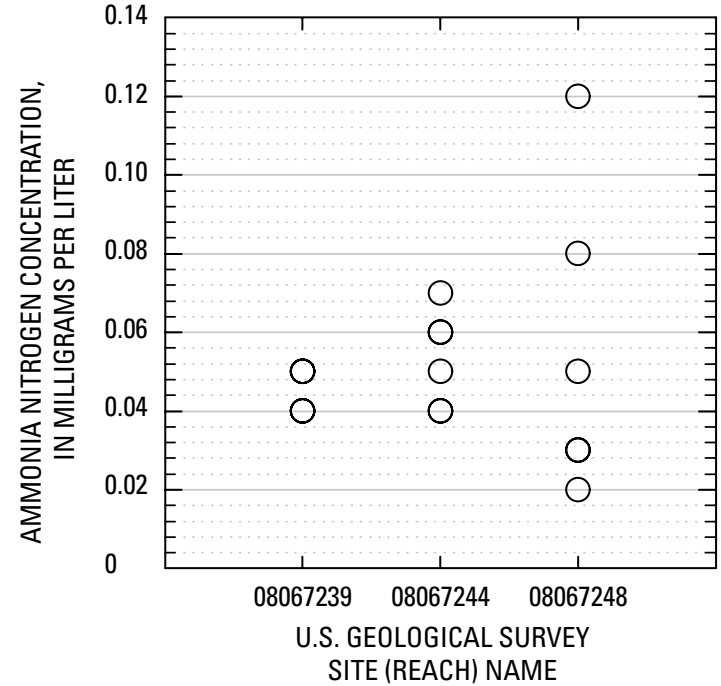

D.

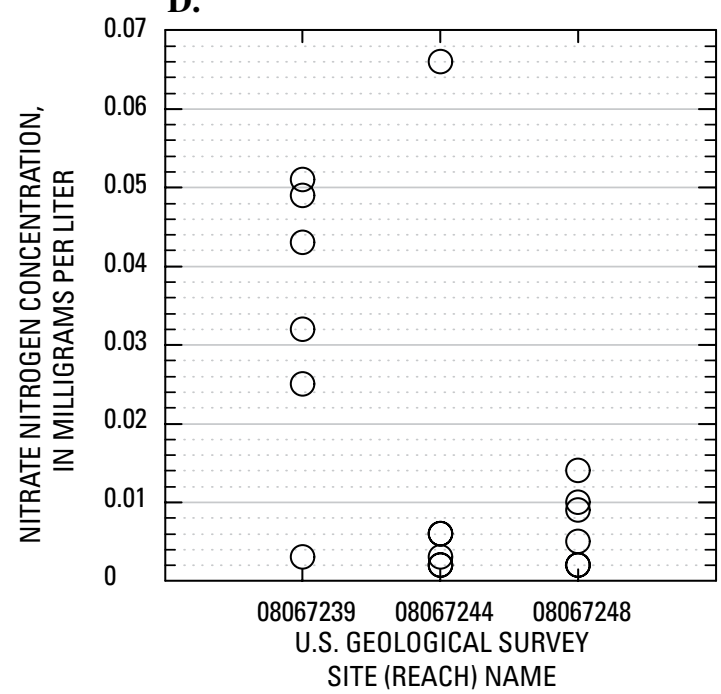

F.

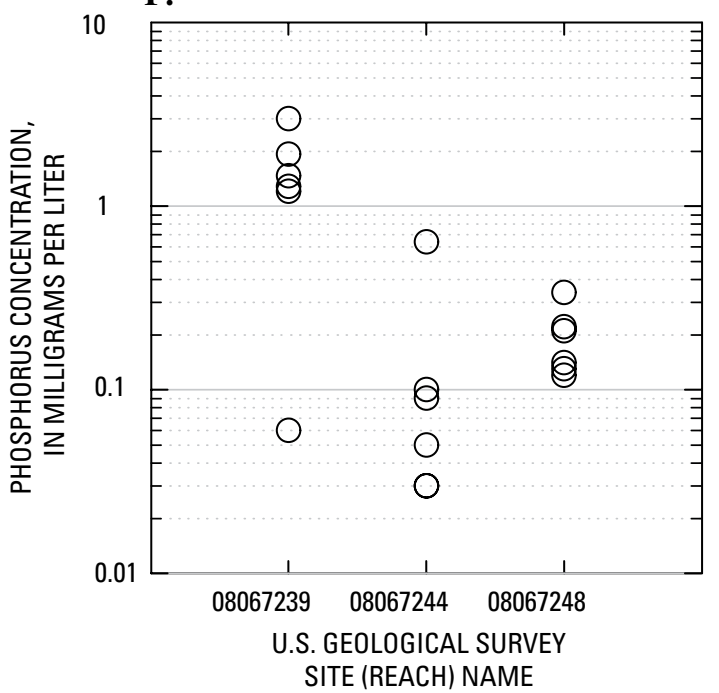

Figure 6. Distribution by site of $(A)$ ammonia plus organic nitrogen, $(B)$ ammonia nitrogen, $(C)$ nitrate plus nitrite nitrogen, (D) nitrite nitrogen, (E) orthophosphate phosphorus, and (F) total phosphorus in samples from three sites (reaches), Cotton Bayou (08067239, 08067248) and Hackberry Gully (08067244), Chambers County, Texas, 2006-07. 
A.

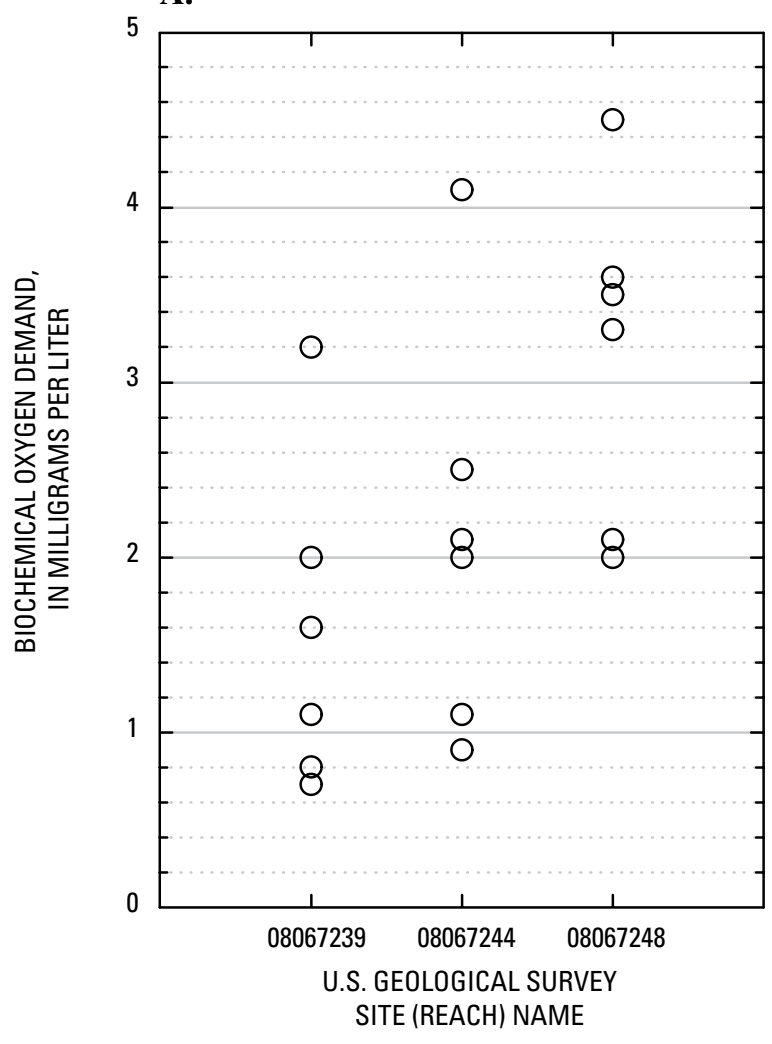

B.

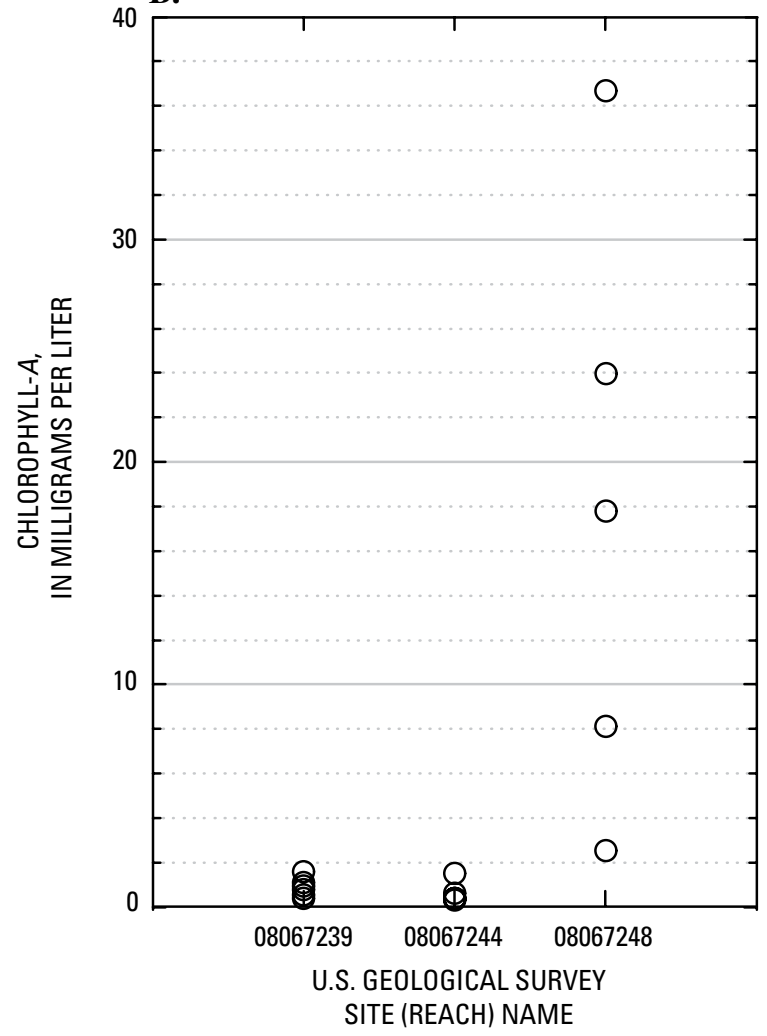

C.

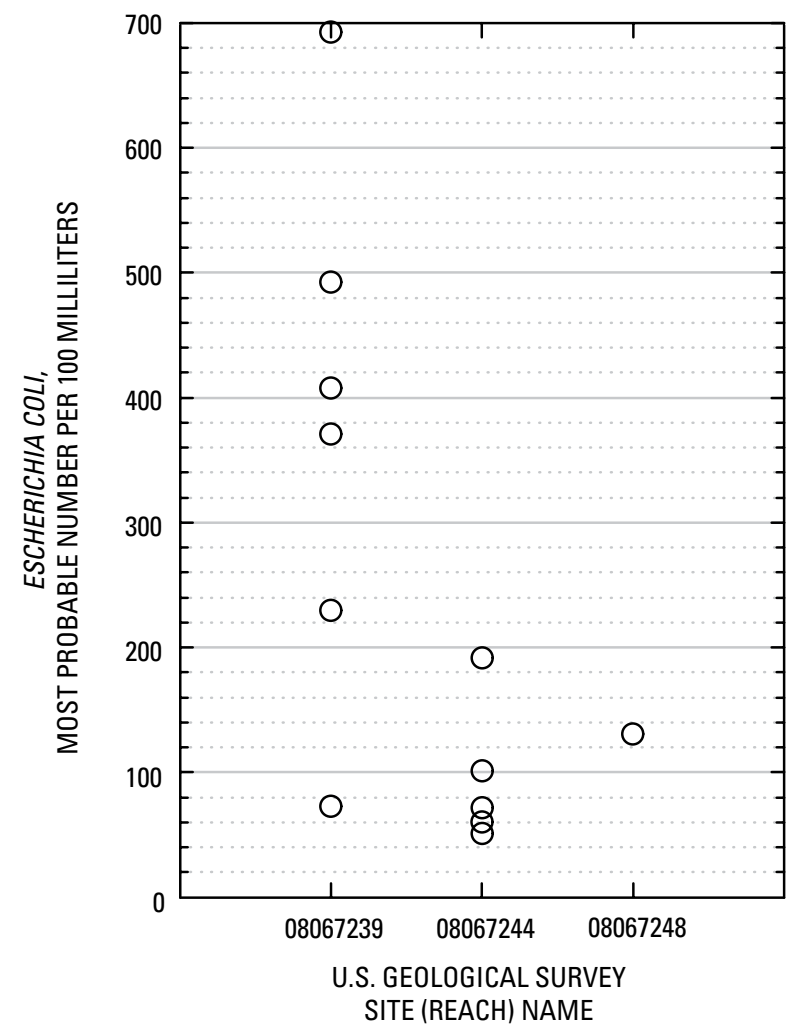

Figure 7. Distribution by site of (A) biochemical oxygen demand, (B) chlorophyll-a, and (C) Escherichia coli in samples from three sites (reaches), Cotton Bayou (08067239, 08067248) and Hackberry Gully (08067244), Chambers County, Texas, 2006-07. 
Table 4. Summary of 24-hour specific conductance data collected at five sites (reaches), West Fork Double Bayou (08042550, 08042554), Cotton Bayou (08067239, 08067248), and Hackberry Gully (08067244), Chambers County, Texas, 2006-07.

[USGS, U.S. Geological Survey; --, no data]

\begin{tabular}{|c|c|c|c|c|c|c|c|c|}
\hline \multirow{2}{*}{$\begin{array}{c}\text { USGS } \\
\text { site (reach) } \\
\text { number } \\
\text { (fig. 1) }\end{array}$} & \multirow{2}{*}{ Statistic } & \multicolumn{7}{|c|}{$\begin{array}{c}\text { Measured specific conductance } \\
\text { (microsiemens per centimeter at } 25 \text { degrees Celsius) }\end{array}$} \\
\hline & & $\begin{array}{l}\text { July } \\
2006\end{array}$ & $\begin{array}{l}\text { August } \\
2006\end{array}$ & $\begin{array}{l}\text { October } \\
2006\end{array}$ & $\begin{array}{c}\text { March } \\
2007\end{array}$ & $\begin{array}{l}\text { May } \\
2007\end{array}$ & $\begin{array}{l}\text { June } \\
2007\end{array}$ & $\begin{array}{l}\text { August } \\
2007\end{array}$ \\
\hline \multirow[t]{3}{*}{08042550} & Maximum & -- & -- & -- & -- & -- & -- & 223 \\
\hline & Minimum & -- & -- & -- & -- & -- & -- & 220 \\
\hline & Mean & -- & -- & -- & -- & -- & -- & 222 \\
\hline \multirow[t]{3}{*}{08042554} & Maximum & -- & 223 & -- & -- & -- & -- & 319 \\
\hline & Minimum & -- & 178 & -- & -- & -- & -- & 182 \\
\hline & Mean & -- & 189 & -- & -- & -- & -- & 278 \\
\hline \multirow[t]{3}{*}{08067239} & Maximum & 1,240 & -- & 1,220 & 1,330 & 1,030 & -- & 1,180 \\
\hline & Minimum & 1,120 & -- & 1,190 & 358 & 929 & -- & 354 \\
\hline & Mean & 1,220 & -- & 1,200 & 750 & 997 & -- & 803 \\
\hline \multirow[t]{3}{*}{08067244} & Maximum & 414 & -- & 482 & 899 & 695 & -- & 633 \\
\hline & Minimum & 402 & -- & 453 & 252 & 662 & -- & 608 \\
\hline & Mean & 408 & -- & 467 & 557 & 682 & -- & 615 \\
\hline \multirow[t]{3}{*}{08067248} & Maximum & 2,220 & 638 & -- & 943 & 375 & 698 & 526 \\
\hline & Minimum & 767 & 440 & -- & 337 & 320 & 468 & 446 \\
\hline & Mean & 1,330 & 513 & -- & 687 & 342 & 610 & 502 \\
\hline
\end{tabular}

Table 5. Summary of 24-hour dissolved oxygen data collected at five sites (reaches), West Fork Double Bayou (08042550, 08042554), Cotton Bayou (08067239, 08067248), and Hackberry Gully (08067244), Chambers County, Texas, 2006-07.

[USGS, U.S. Geological Survey; n/a, not applicable; --, no value]

\begin{tabular}{|c|c|c|c|c|c|c|c|c|c|c|}
\hline \multirow{2}{*}{$\begin{array}{l}\text { USGS site } \\
\text { (reach) } \\
\text { number } \\
\text { (fig. 1) }\end{array}$} & \multirow{2}{*}{ Statistic } & \multirow{2}{*}{$\begin{array}{l}\text { Dissolved } \\
\text { oxygen } \\
\text { criteria }{ }^{1} \\
\text { (milligrams } \\
\text { per liter) }\end{array}$} & \multicolumn{7}{|c|}{$\begin{array}{l}\text { Measured dissolved oxygen } \\
\text { (milligrams per liter) }\end{array}$} & \multirow{2}{*}{$\begin{array}{l}\text { Number of monitoring } \\
\text { periods dissolved } \\
\text { oxygen less than } \\
\text { standard }\end{array}$} \\
\hline & & & $\begin{array}{l}\text { July } \\
2006\end{array}$ & $\begin{array}{c}\text { August } \\
2006\end{array}$ & $\begin{array}{l}\text { October } \\
2006\end{array}$ & $\begin{array}{c}\text { March } \\
2007\end{array}$ & $\begin{array}{l}\text { May } \\
2007\end{array}$ & $\begin{array}{l}\text { June } \\
2007\end{array}$ & $\begin{array}{c}\text { August } \\
2007\end{array}$ & \\
\hline \multirow[t]{2}{*}{08042550} & Maximum & $\mathrm{n} / \mathrm{a}$ & -- & -- & -- & -- & -- & -- & 5.50 & $\mathrm{n} / \mathrm{a}$ \\
\hline & Minimum & 3.0 & -- & -- & -- & -- & -- & -- & 4.10 & 0 \\
\hline \multirow[t]{3}{*}{08042554} & Maximum & $\mathrm{n} / \mathrm{a}$ & -- & 2.70 & -- & -- & -- & -- & 9.40 & $\mathrm{n} / \mathrm{a}$ \\
\hline & Minimum & 3.0 & -- & 1.40 & -- & -- & -- & -- & 4.20 & 1 \\
\hline & Mean & 4.0 & -- & 1.90 & -- & -- & -- & -- & 6.70 & 1 \\
\hline \multirow[t]{2}{*}{08067239} & Maximum & $\mathrm{n} / \mathrm{a}$ & 5.00 & -- & 5.00 & 7.60 & 6.90 & -- & 7.00 & $\mathrm{n} / \mathrm{a}$ \\
\hline & Minimum & 3.0 & 4.60 & -- & 4.10 & 5.20 & 6.20 & -- & 5.50 & 0 \\
\hline 08067244 & Mean & 4.0 & 4.10 & -- & 4.10 & 5.10 & 3.00 & -- & 1.50 & 2 \\
\hline \multirow[t]{3}{*}{08067248} & Maximum & $\mathrm{n} / \mathrm{a}$ & 6.50 & 3.60 & -- & 7.70 & 8.50 & 5.80 & 7.00 & $\mathrm{n} / \mathrm{a}$ \\
\hline & Minimum & 3.0 & 2.00 & 2.50 & -- & 3.20 & 5.70 & 5.20 & 4.00 & 2 \\
\hline & Mean & 4.0 & 3.00 & 2.80 & -- & 5.00 & 6.60 & 5.30 & 5.20 & 2 \\
\hline
\end{tabular}

\footnotetext{
${ }^{1}$ Texas Commission on Environmental Quality, 2003a.
} 


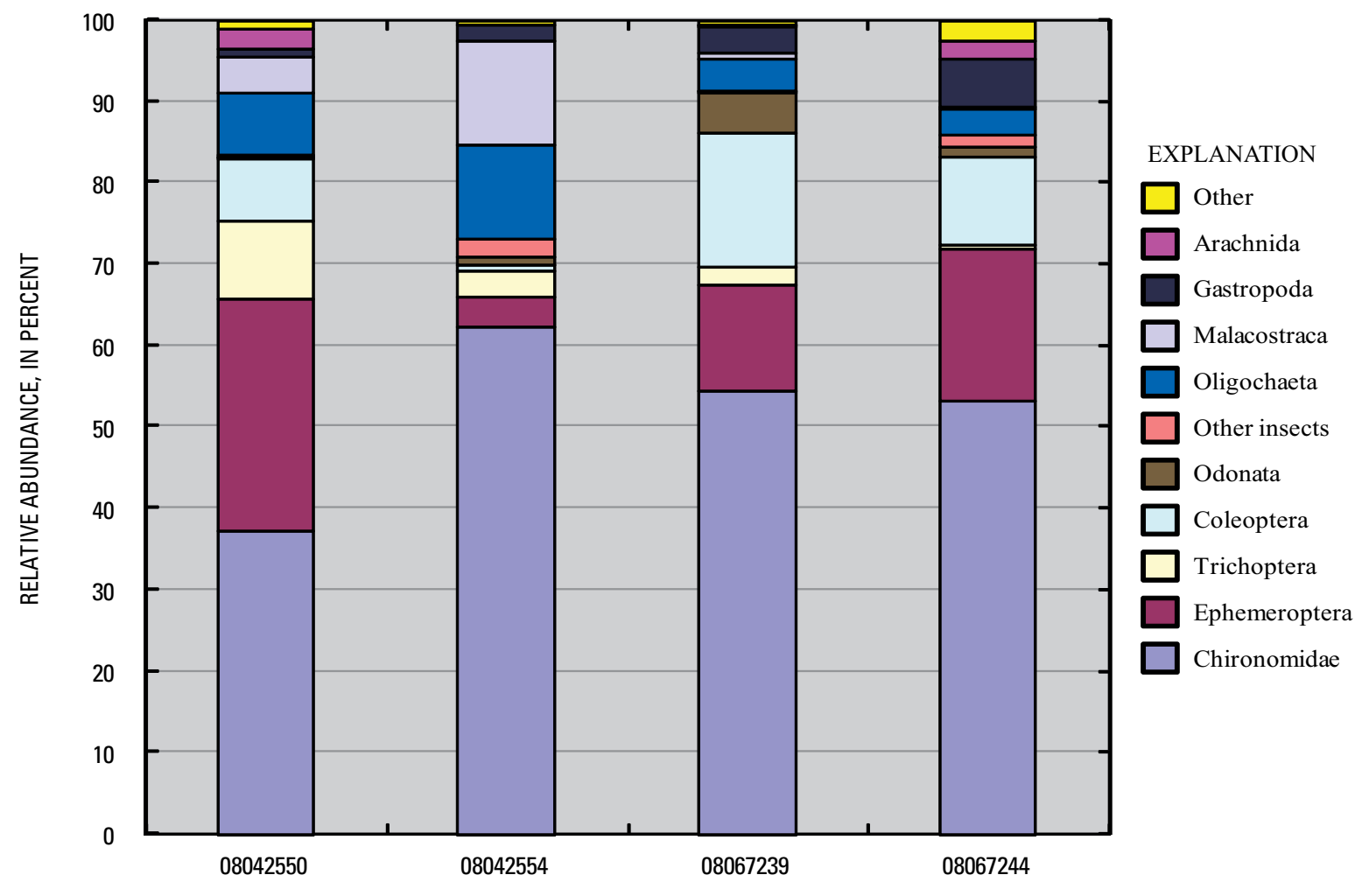

U.S. GEOLOGICAL SURVEY SITE (REACH) NUMBER

Figure 8. Relative abundance of benthic macroinvertebrates for representative reach at each of four sites, West Fork Double Bayou (08042550, 08042554), Cotton Bayou (08067239), and Hackberry Gully (08067244), Chambers County, Texas, 2006-07.

reach (08067244) (appendix 4). The dominant substrate at all reaches except 08042554 was mud/silt; the dominant substrate at 08042554 was sand. No riffles were observed at any reach during the study period. Instream cover which provides habitat for benthic macroinvertebrates and fish, consisted primarily of woody debris, root wads, macrophytes, algae, and vegetation overhanging from the banks. Canopy cover was generally high and averaged 75.2 percent across all reaches. Data and computed metrics that describe habitat for each reach and survey are in appendix 4.

Characteristics of habitat measured during each assessment were scored using a habitat quality index (Texas Commission on Environmental Quality, 2007) (table 6). Habitat quality index scores ranged from 14 to 20 and generally indicated "intermediate" aquatic life use at most reaches. Three habitat quality index scores (two at reach 08042554 and one at reach 08067244) indicated "high" aquatic life use; however, all three scores were the same (20) and were the minimum (score of 20 to 25) for classification as "high" aquatic life use.

\section{Biological Data}

Benthic macroinvertebrate and fish data were collected at the two West Fork Double Bayou reaches (08042550,
08042554), one Cotton Bayou reach (08067239), and Hackberry Gully reach (08067244). Three assessments were done at each reach: July-August 2006, March 2007, and JulyAugust 2007.

\section{Benthic Macroinvertebrates}

A total of 2,572 macroinvertebrate individuals from the four reaches were identified (appendix 5) consisting of 415 individuals belonging to benthic, non-insect invertebrate taxa and 2,157 individuals belonging to insect taxa. The largest number of individuals (286) was collected at reach 08067239 in March 2007. The smallest number of individuals (140) was collected at reach 08042554 in August 2006. Overall, the most abundant benthic macroinvertebrates belonged to the family Chironomidae (non-biting midges). Other abundant groups of benthic macroinvertebrates were the orders Ephemeroptera (mayflies) and Coleoptera (beetles), the subclass Oligochaeta, and the class Malacostraca (appendix 5). Insect taxa were more abundant than non-insect taxa at all reaches (fig. 8).

Characteristic habitat for benthic macroinvertebrate communities at these reaches includes low water velocities, elevated water temperatures, silt and clay substrate, cutbanks, rootmass, macrophyte growth, and generally abundant canopy cover. West Fork Double Bayou (08042554), Cotton Bayou 
Table 6. Scores for stream-habitat metrics and habitat quality index for representative reach at each of four sites, West Fork Double Bayou (08042550, 08042554), Cotton Bayou (08067239), and Hackberry Gully (08067244), Chambers County, Texas, $2006-07$.

\begin{tabular}{|c|c|c|c|c|c|c|c|c|c|c|c|c|}
\hline \multirow{2}{*}{$\begin{array}{l}\text { Stream-habitat } \\
\text { metric }\end{array}$} & \multicolumn{3}{|c|}{08042550} & \multicolumn{3}{|c|}{08042554} & \multicolumn{3}{|c|}{08067239} & \multicolumn{3}{|c|}{08067244} \\
\hline & $\begin{array}{c}\text { August } \\
2006\end{array}$ & $\begin{array}{c}\text { March } \\
2007\end{array}$ & $\begin{array}{c}\text { August } \\
2007\end{array}$ & $\begin{array}{c}\text { August } \\
2006\end{array}$ & $\begin{array}{c}\text { March } \\
2007\end{array}$ & $\begin{array}{c}\text { August } \\
2007\end{array}$ & $\begin{array}{l}\text { July } \\
2006\end{array}$ & $\begin{array}{c}\text { March } \\
2007\end{array}$ & $\begin{array}{c}\text { August } \\
2007\end{array}$ & $\begin{array}{l}\text { July } \\
2006\end{array}$ & $\begin{array}{c}\text { March } \\
2007\end{array}$ & $\begin{array}{l}\text { July } \\
2007\end{array}$ \\
\hline Riffles & 1 & 1 & 1 & 1 & 1 & 1 & 1 & 1 & 1 & 1 & 1 & 1 \\
\hline Pools & 1 & 1 & 1 & 1 & 1 & 1 & 1 & 1 & 1 & 1 & 1 & 1 \\
\hline \multicolumn{13}{|l|}{ Bank stability: } \\
\hline Erosion component & 2 & 2 & 1 & 3 & 2 & 2 & 1 & 1 & 1 & 1 & 2 & 2 \\
\hline Riparian buffer vegetation & 3 & 3 & 3 & 3 & 3 & 3 & 3 & 3 & 3 & 3 & 3 & 3 \\
\hline Channel flow status & 2 & 2 & 2 & 2 & 2 & 2 & 2 & 2 & 2 & 2 & 2 & 2 \\
\hline Channel sinuosity & 2 & 2 & 2 & 3 & 3 & 3 & 1 & 1 & 1 & 2 & 2 & 3 \\
\hline Habitat quality index & 16 & 15 & 15 & 20 & 18 & 20 & 14 & 14 & 15 & 16 & 17 & 20 \\
\hline Aquatic-life-use category $^{1}$ & $\mathrm{I}$ & $\mathrm{I}$ & $\mathrm{I}$ & $\mathrm{H}$ & $\mathrm{I}$ & $\mathrm{H}$ & $\mathrm{I}$ & $\mathrm{I}$ & $\mathrm{I}$ & $\mathrm{I}$ & $\mathrm{I}$ & $\mathrm{H}$ \\
\hline
\end{tabular}

${ }^{1}$ Texas Commission on Environmental Quality (2007); I, intermediate (14-19); H, high (20-25).

(08067248) and Hackberry Gully (08067244) had very low dissolved oxygen (less than $3.0 \mathrm{mg} / \mathrm{L}$ ) during at least one sampling period (table 5).

The number of insect individuals collected during all surveys ranged from 416 at reach 08042554 to 627 at reach 08067239 (appendix 5). The most abundant insect at each reach was Fallceon quilleri (Insecta) at 08042550; Tribelos sp. (Insecta) at 08042554; Rheotanytarsus exiguus gr. (Insecta) at 08067239; and Dicrotendipes sp. (Insecta) at 08067244.

The composition of an invertebrate community, the relative abundance of tolerant versus intolerant specimens, and the distribution of trophic (feeding) groups reflect the aquatic health of the water (Thomas and others, 2002; Skrobialowski and others, 2004). Benthic macroinvertebrate assemblages were scored using aquatic health indicator metrics specified by the Texas Commission on Environmental Quality (2007). The metric scores were then summed to calculate a final aquaticlife use score for each reach. Aquatic-life-use scores (table 7) were generally "high" at three of the four study reaches (08042550, 08067239, 08067244). However, samples were classified as "intermediate" during one survey each at reaches 08042550 (August 2006) and 08067244 (July 2006) and during all surveys at reach 08042554 . The "intermediate" scores were generally associated with reduced values of metrics such as taxa richness, EPT taxa abundance (richness), percentage of dominant taxon, percentage dominant functional feeding group, percentage of Elmidae, and percentage of collectorgatherers.

Taxa richness is the total number of benthic invertebrate taxa identified in a sample. Reduced taxa richness value of a reach relative to other similar reaches can be an indicator of physiochemical disturbance and reduced biotic integrity (Texas Commission on Environmental Quality, 2007). West Fork Double Bayou had reduced taxa richness values (relative to other reaches) in three of six samples (August 2006 at 08042550; August 2006 and March 2007 at 08042554).

Ephemeroptera, Plecoptera, Tricoptera (EPT) taxa presence and abundance (table 7) provide a measure of environmental quality in freshwater streams (Moring, 2003). This metric tends to decrease in response to increasing disturbance from physiochemical factors (Texas Commission on Environmental Quality, 2007). The scores of EPT taxa (richness) from individual surveys in all reaches in the study ranged from 1 to 3 out of a possible score of 4 . Insects of the order Plecoptera (stoneflies), which are generally associated with cooler oxygenated waters and cobble substrates and which are not commonly found in streams of the Texas Gulf Coast, were not collected at any reaches. Insects of the order Ephemeroptera (mayflies) were relatively abundant at all reaches. Some Tricoptera taxa were found at all reaches, but were relatively abundant only at reach 08042550 . EPT taxa scores across all four study reaches (table 7) were generally lowest at reach 08042554.

The percentage dominant taxon is calculated as the ratio of the number of individuals in the most numerically abundant taxon to the total number of individuals in the sample, multiplied by 100 . This metric increases as more of the sample is composed of a single taxon and could indicate an imbalanced community structure and environmental stress (Texas Commission on Environmental Quality, 2007). Relatively 
Table 7. Scores for benthic macroinvertebrate metrics and aquatic life use for representative reach at each of four sites, West Fork Double Bayou (08042550, 08042554), Cotton Bayou (08067239), and Hackberry Gully (08067244), Chambers County, Texas, 2006-07.

[EPT, Epheroptera, Plecoptera, Trichoptera; L, limited (less than 22); I, intermediate (22-28); H, high (29-36)]

\begin{tabular}{|c|c|c|c|c|c|c|c|c|c|c|c|c|}
\hline \multirow{2}{*}{$\begin{array}{c}\text { Benthic } \\
\text { macroinvertebrate metric }\end{array}$} & \multicolumn{3}{|c|}{08042550} & \multicolumn{3}{|c|}{08042554} & \multicolumn{3}{|c|}{08067239} & \multicolumn{3}{|c|}{08067244} \\
\hline & $\begin{array}{c}\text { August } \\
2006\end{array}$ & $\begin{array}{c}\text { March } \\
2007\end{array}$ & $\begin{array}{c}\text { August } \\
2007\end{array}$ & $\begin{array}{c}\text { August } \\
2006\end{array}$ & $\begin{array}{c}\text { March } \\
2007\end{array}$ & $\begin{array}{c}\text { August } \\
2007\end{array}$ & $\begin{array}{l}\text { July } \\
2006\end{array}$ & $\begin{array}{c}\text { March } \\
2007\end{array}$ & $\begin{array}{c}\text { August } \\
2007\end{array}$ & $\begin{array}{l}\text { July } \\
2006\end{array}$ & $\begin{array}{c}\text { March } \\
2007\end{array}$ & $\begin{array}{l}\text { July } \\
2007\end{array}$ \\
\hline EPT taxa abundance & 2 & 3 & 3 & 2 & 1 & 1 & 2 & 2 & 2 & 2 & 1 & 2 \\
\hline Hilsenhoff biotic index (HBI) & 1 & 1 & 1 & 1 & 1 & 1 & 1 & 1 & 1 & 1 & 1 & 1 \\
\hline Percentage predators & 4 & 4 & 4 & 4 & 1 & 4 & 3 & 4 & 3 & 4 & 3 & 4 \\
\hline Ratio of intolerant to tolerant taxa & 1 & 1 & 1 & 1 & 1 & 1 & 1 & 1 & 1 & 1 & 1 & 1 \\
\hline $\begin{array}{l}\text { Percentage total Trichoptera as } \\
\text { Hydropsychidae }\end{array}$ & 1 & 1 & 1 & 4 & 4 & 4 & 1 & 2 & 1 & 1 & 4 & 4 \\
\hline Percentage Chironomidae & 1 & 1 & 1 & 1 & 1 & 1 & 1 & 1 & 1 & 1 & 1 & 1 \\
\hline Percentage collector-gatherers & 2 & 2 & 2 & 1 & 1 & 1 & 3 & 3 & 2 & 1 & 2 & 1 \\
\hline Total score & 27 & 32 & 31 & 23 & 23 & 25 & 29 & 30 & 29 & 27 & 31 & 31 \\
\hline Aquatic life use ${ }^{1}$ & $\mathrm{I}$ & $\mathrm{H}$ & $\mathrm{H}$ & $\mathrm{I}$ & $\mathrm{I}$ & I & $\mathrm{H}$ & $\mathrm{H}$ & $\mathrm{H}$ & $\mathrm{I}$ & $\mathrm{H}$ & $\mathrm{H}$ \\
\hline
\end{tabular}

${ }^{1}$ Texas Commission on Environmental Quality (2007); I, intermediate (22-28); H, high (29-36).

high percentage dominant taxa values correspond to low scores for aquatic life use as indicated for reach 08067239 in March 2007 and for reach 08042554 in August 2006 and 2007 (table 7).

Increased values for two related metrics, percentage dominant functional feeding group (pDFFG) and percentage collector-gatherers ( $\mathrm{pCG}$ ), contributed to reduced aquatic-lifeuse scores in reach 08042554 (table 7). The pDFFG metric is the ratio of the number of individuals in the most numerically abundant functional feeding group to the total number of individuals in the sample, multiplied by 100 ; the pCG metric is the ratio of the number of individuals in the collector-gatherer functional feeding group to the total number of individuals in the sample, multiplied by 100 . These metrics are related to the premise that physiochemical disturbances can alter the resource base available to benthic macroinvertebrate consumers and create an imbalanced trophic structure (Texas Commission on Environmental Quality, 2007). More specifically, an increase in pCG can indicate an increase in fine particulate organic matter and increased organic enrichment. The collector-gatherer functional group was the dominant feeding group across all reaches and samples, but pCG was relatively larger at reach 08042554 .

Some of the increase in pCG may be related to the relative position of reach 08042554 on the stream segment. Vannote and others (1980) proposed that the types of mac- roinvertebrate communities in rivers form a continuum from the headwaters to the mouth and correlate with the sources of nutrition in the rivers. Smaller streams of the headwaters would be dominated by macroinvertebrates that are capable of using coarser vegetation (shredders and scrapers); macroinvertebrates that could use finer organic particulate matter (filterers and gatherers) would increase in number downstream. Reach 08042554 was the most downstream reach sampled in this study, thus some of the increase in pCG might be attributed to a natural change in the resource base.

\section{Fish}

Thirty species of fish representing 13 families were collected for a total of 1,082 fish; fish taxa and individual counts from each survey are listed in appendix 6 . Western mosquitofish (Gambusi affinis) was the most abundant species with 406 individuals collected. Several species were represented by only one individual: Achirus lineatus (lined sole); Atractosteus spatula (alligator gar); and Ictalurus punctatus (channel catfish).

A tolerance rating and trophic group were assigned to each species (Linam and Kleinsasser, 1998). An index of biotic integrity (table 8 ) was calculated for the combined catch for each survey at the reaches using scoring indexes developed to assess stream fish assemblages in the Western Gulf Coastal 
Table 8. Scores for fish metrics and index of biotic integrity for representative reach at each of four sites, West Fork Double Bayou (08042550, 08042554), Cotton Bayou (08067239), and Hackberry Gully (08067244), Chambers County, Texas, $2006-07$.

[N/A, not applicable]

\begin{tabular}{|c|c|c|c|c|c|c|c|c|c|c|c|c|}
\hline \multirow[b]{2}{*}{ Fish metric } & \multicolumn{3}{|c|}{08042550} & \multicolumn{3}{|c|}{08042554} & \multicolumn{3}{|c|}{08067239} & \multicolumn{3}{|c|}{08067244} \\
\hline & $\begin{array}{c}\text { August } \\
2006\end{array}$ & $\begin{array}{c}\text { March } \\
2007\end{array}$ & $\begin{array}{c}\text { August } \\
2007\end{array}$ & $\begin{array}{c}\text { August } \\
2006\end{array}$ & $\begin{array}{c}\text { March } \\
2007\end{array}$ & $\begin{array}{c}\text { August } \\
2007\end{array}$ & $\begin{array}{l}\text { July } \\
2006\end{array}$ & $\begin{array}{c}\text { March } \\
2007\end{array}$ & $\begin{array}{c}\text { August } \\
2007\end{array}$ & $\begin{array}{l}\text { July } \\
2006\end{array}$ & $\begin{array}{c}\text { March } \\
2007\end{array}$ & $\begin{array}{l}\text { July } \\
2007\end{array}$ \\
\hline Number of native cyprinid species & 1 & 3 & 1 & 1 & 1 & 1 & 1 & 5 & 1 & 1 & 1 & 1 \\
\hline Number of benthic invertivore species & 1 & 1 & 1 & 1 & 1 & 1 & 1 & 1 & 1 & 1 & 1 & 1 \\
\hline $\begin{array}{l}\text { Percent of individuals as tolerant } \\
\quad \text { (excluding western mosquitofish) }\end{array}$ & 5 & 5 & 3 & 3 & 3 & 3 & 3 & 5 & 5 & 3 & 3 & 5 \\
\hline Percent individuals as omnivores & 5 & 5 & 5 & 5 & 1 & 1 & 3 & 5 & 1 & 5 & 5 & 5 \\
\hline Percent individuals as invertivores & 5 & 5 & 5 & 3 & 3 & 3 & 5 & 5 & 3 & 5 & 5 & 5 \\
\hline Percent individuals as nonnative species & 5 & 5 & 5 & 5 & 5 & 5 & 5 & 5 & 5 & 5 & 5 & 5 \\
\hline $\begin{array}{l}\text { Percent individuals with diseases or } \\
\text { anomolies }\end{array}$ & 5 & 5 & 5 & 5 & 5 & 5 & 5 & 5 & 5 & 5 & 5 & 5 \\
\hline Total score (ecoregion 34) & 41 & 41 & 37 & 35 & 33 & 31 & 33 & 47 & 31 & 36 & 39 & 38 \\
\hline Index of biotic integrity ${ }^{1}$ & $\mathrm{H}$ & $\mathrm{H}$ & I & $\mathrm{I}$ & I & $\mathrm{I}$ & $\mathrm{I}$ & $\mathrm{H}$ & I & I & $\mathrm{H}$ & I \\
\hline
\end{tabular}

${ }^{1}$ Linam and others (2002), Texas Commission on Environmental Quality (2007); H, high aquatic life use (39-48); I, intermediate aquatic life use (31-38).

Plain (ecoregion 34) (Linam and others, 2002). Index of biotic integrity scores ranged from 31 to 47 across all reaches, indicating "high" aquatic life use (scores of 39 to 48) during two surveys at reach 08042550 (August and March 2006) and one survey each at reaches 08067239 and 08067244 (March 2007); and "intermediate" aquatic life use (scores of 31 to 38) during the remaining surveys at reaches 08042550,08067239 , and 08067244 and all surveys at reach 08042554 .

Nine fish species were identified as having a specific tolerance or intolerance to pollution (Linam and Kleinsasser, 1998). Eight of the species were classified as tolerant and are identified in appendix 6 . These include 406 individuals of western mosquitofish (Gambusi affinis); 213 individuals of three sunfish species (Lepomis macrochirus, Lepomis cyanellus, Lepomis gulosus); 25 individuals of two gar species (Atractosteus spatula, Lepisosteus oculatus); 1 channel catfish (Ictalurus punctatus); and 1 gizzard shad (Dorosoma cepedianum).

One species, the mimic shiner (Notropis volucellus), was classified as intolerant to pollution (Linam and Kleinsasser, 1998). Eight mimic shiners were collected in March 2007; seven at 08067239 and one at 08067244 .

The presence and relative abundance of tolerant and intolerant fish reflect general stream conditions. Intolerant fish species indicate high and moderate quality reaches (Linam and Kleinsasser, 1998) and become increasingly scarce with pollution or destruction of suitable habitat. Tolerant fish species increase in distribution and abundance when reach conditions are less favorable, becoming dominant in disturbed reaches (Linam and Kleinsasser, 1998). Tolerant species are dominant at all reaches in this study. However, because all reaches in the study area are located in the Gulf Coastal Plain (ecoregion 34 ), the distribution of tolerant and intolerant species does not necessarily reflect pollution. Common, naturally occurring characteristics of coastal streams, including mud and sand substrate, slow velocities, absence of riffles, little tree canopy, and variable water quality, might limit intolerant species.

Fish species can be separated into trophic groups that describe the manner in which they feed. The three trophic (feeding) groups are omnivores (generalized feeders); invertivores (feed on invertebrates, mostly insects); and piscivores (feed on other fish). At West Fork Double Bayou, the majority of fish were invertivores, 90 percent at 08042550 and 47 percent at 08042554 (fig. 9); the next most abundant were piscivores, 9.7 percent at 08042550 and 23 percent at 08042554; then omnivores, 1.4 percent at 08042550 and 31 percent at 08042554. At Cotton Bayou and Hackberry Gully, the majority of fish were invertivores, 78 percent at 08067239 


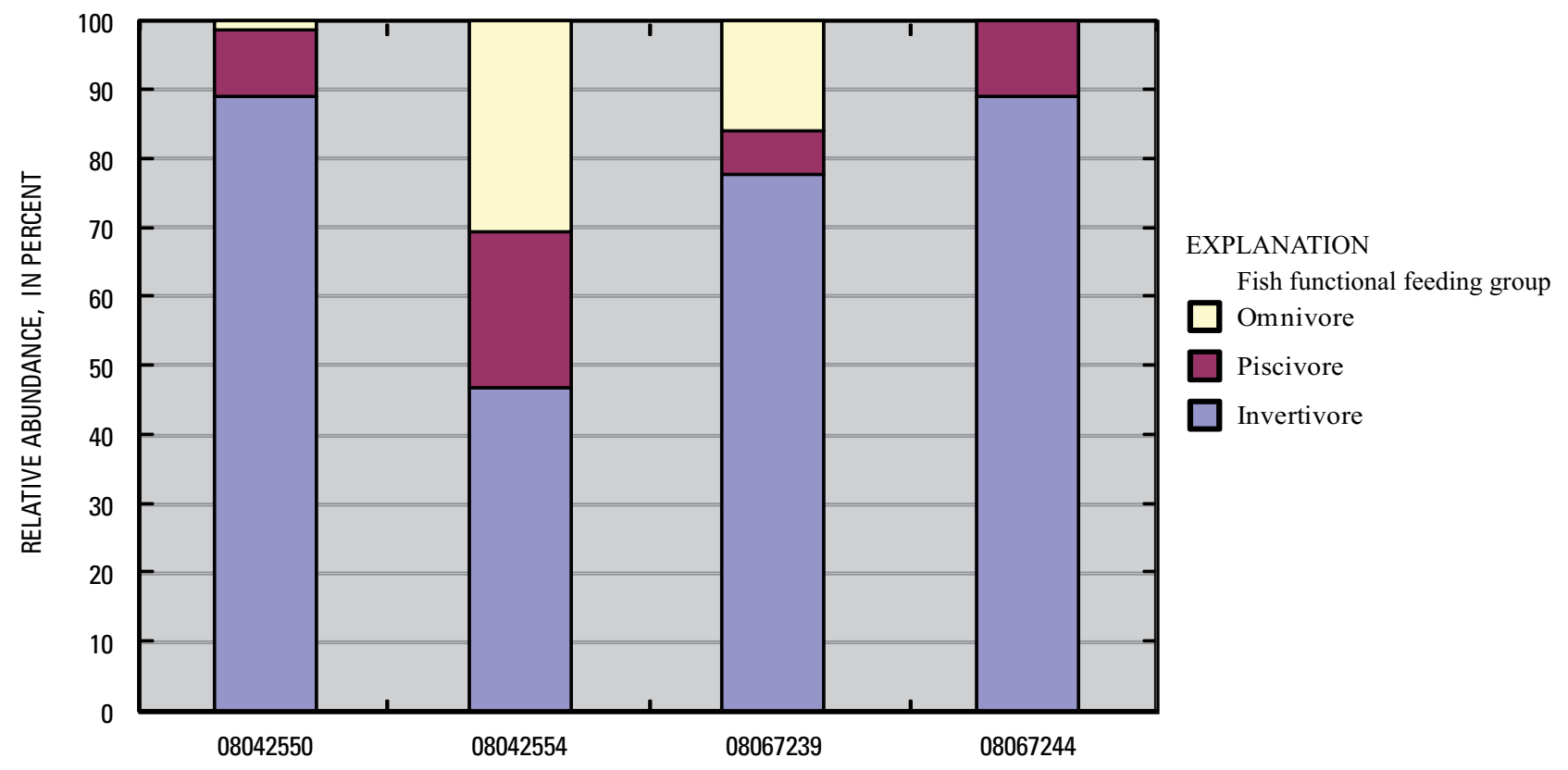

U.S. GEOLOGICAL SURVEY SITE (REACH) NUMBER

Figure 9. Relative abundance of fish functional feeding groups for representative reach at each of four sites, West Fork Double Bayou (08042550, 08042554), Cotton Bayou (08067239), and Hackberry Gully (08067244), Chambers County, Texas, 2006-07.

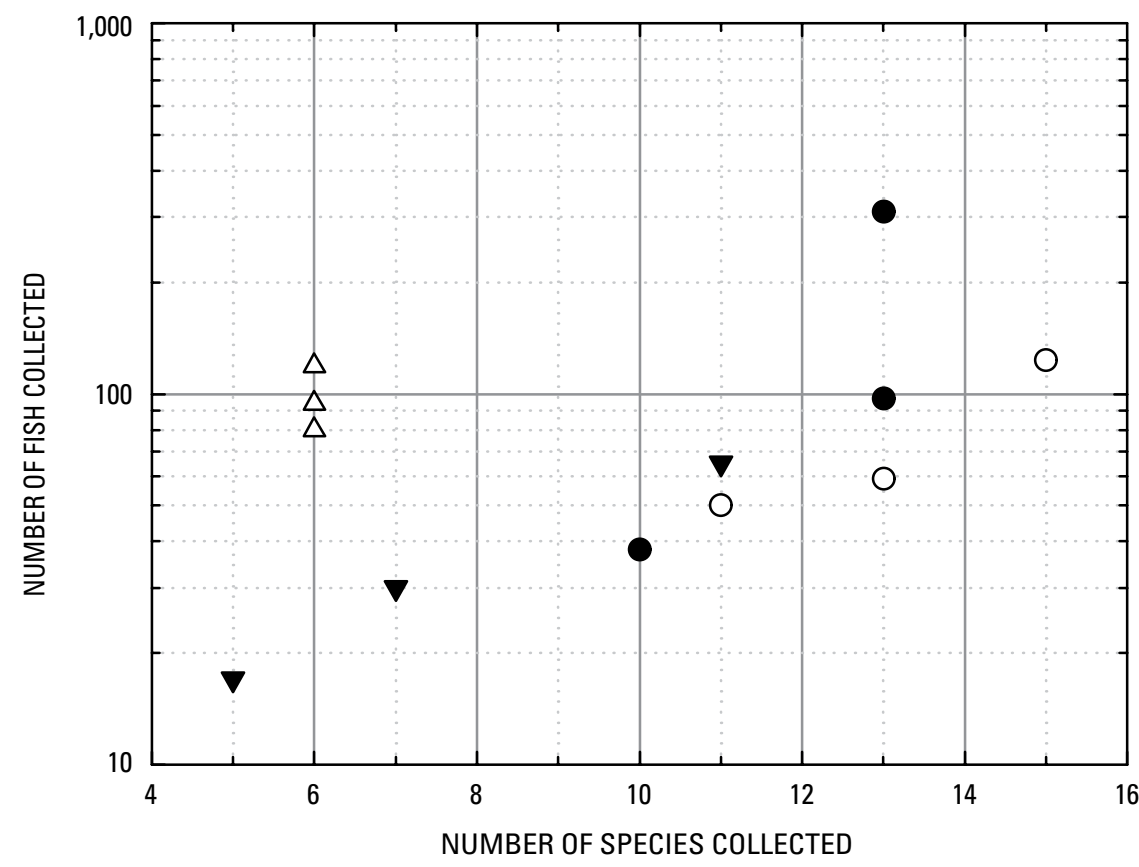

\section{EXPLANATION}

U.S. Geological Survey site (reach) number

08042550

○ 08042554

$\boldsymbol{\nabla} 08067239$

$\triangle 08067244$

Figure 10. Number of fish collected relative to number of fish species from representative reach at each of four sites, West Fork Double Bayou (08042550, 08042554), Cotton Bayou (08067239), and Hackberry Gully (08067244), Chambers County, Texas, 2006-07. 
Table 9. Average aquatic-life-use indicated by stream habitat, benthic macroinvertebrates, and fish for representative reach at each of four sites, West Fork Double Bayou (08042550, 08042554), Cotton Bayou (08067239), and Hackberry Gully (08067244), Chambers County, Texas, 2006-07.

[I, intermediate; $\mathrm{H}$, high; L, limited]

\begin{tabular}{lcccc}
\hline \multirow{2}{*}{ Category indicator } & \multicolumn{4}{c}{ Average aquatic life use } \\
\cline { 2 - 5 } & $\mathbf{0 8 0 4 2 5 5 0}$ & $\mathbf{0 8 0 4 2 5 5 4}$ & $\mathbf{0 8 0 6 7 2 3 9}$ & $\mathbf{0 8 0 6 7 2 4 4}$ \\
\hline Stream habitat $^{1}$ & $\mathrm{I}$ & $\mathrm{I}$ & $\mathrm{I}$ & $\mathrm{I}$ \\
Benthic macroinvertebrates $^{2}$ & $\mathrm{H}$ & $\mathrm{I}$ & $\mathrm{H}$ & $\mathrm{H}$ \\
Fish $^{3}$ & $\mathrm{H}$ & $\mathrm{I}$ & $\mathrm{I}$ & $\mathrm{I}$ \\
\hline
\end{tabular}

${ }^{1}$ Habitat quality index aquatic-life-use scores (Texas Commission on Environmental Quality, 2007).

${ }^{2}$ Benthic macroinvertebrate aquatic-life-use scores (Texas Commission on Environmental Quality, 2007).

${ }^{3}$ Index of biotic integrity aquatic-life-use scores for ecoregion 34 (Linam and others (2002); Texas Commission on Environmental Quality, 2007).

and 89 percent at 08067244 (fig. 9); the next most abundant were piscivores, 6.2 percent at 08067239 and 11 percent at 08067244; then omnivores, 16 percent at 08067239 and 0 at 08067244. Trophic composition metrics may help to evaluate the quality of the stream habitat and chemical quality because more generalized feeders (for example, omnivores) become a larger percentage of the population with degradation of conditions (Linam and Kleinsasser, 1998).

The distribution of the total number of fish collected relative to the number of species from each reach is shown in figure 10. If the number of species is proportional to the number of individuals collected (high sampling efficiency), a graph of data for the reaches would have a linear relation. Departures from linear relation between the number of fish and species can reflect several factors, including sampling efficiency (bias), seasonality, and local reach conditions.

The average aquatic-life-use categories indicated by stream-habitat, macroinvertebrate, and fish data collected between July 2006 and August 2007 are presented in table 9. The average aquatic-life-use category for stream habitat for all reaches was "intermediate." Aquatic life use based on macroinvertebrate data was "intermediate" at reach 08042554 and "high" at reaches 08042550, 08067239, and 08067244. Average aquatic life use based on the index of biotic integrity for fish was "intermediate" at reaches 08042554, 08067239, and 08067244 and "high" at reach 08042550.

\section{Summary}

The Texas Commission on Environmental Quality (TCEQ) administers water-quality management programs with the goal of protecting, maintaining, and restoring water resources in Texas. The Texas Clean Rivers Program (CRP), established by the 1991 Texas Legislature, coordinates water-quality monitoring and assessments in 23 river and coastal basins statewide through contracts with partner agencies. The Houston-Galveston Area Council (H-GAC) is the partner agency for a 13-county area in southeastern Texas that includes the Houston metropolitan area. Every 2 years, CRP partners may perform systematic monitoring studies, whereby a variety of data are collected in water bodies that are not monitored routinely. Data from these special studies help to determine whether additional assessment is needed to evaluate human health concerns, the status of ecological conditions, or designated stream uses.

West Fork Double Bayou, Cotton Bayou, and Hackberry Gully in Chambers County were chosen for this monitoring study. West Fork Double Bayou in eastern Chambers County flows southwestward into Trinity Bay; the watershed is mostly unurbanized. Cotton Bayou in western Chambers County flows southeastward into Cotton Lake, which empties into Trinity Bay; the watershed is mostly unurbanized. The principal tributary to Cotton Bayou is Hackberry Gully.

This report presents the water-quality, stream-habitat, and biological data collected from West Fork Double Bayou, Cotton Bayou, and Hackberry Gully; describes data-collection methods; and presents data to compare water-quality changes at and among sites during the study period.

Data for this report were collected from five sites (reaches) in West Fork Double Bayou, Cotton Bayou, and Hackberry Gully. Water-quality data collected include continuously monitored data-properties measured with a multiprobe instrument at each site- and periodically collected dataproperties and constituents determined from discrete samples collected periodically at the sites.

Four properties (water temperature, $\mathrm{pH}$, specific conductance, and dissolved oxygen) were monitored continuously at the five sites for periods of 24 hours to several days during July, August, and October 2006, and March, May, June, and August 2007. The same four properties plus transparency and turbidity were measured, and chloride, sulfate, residue, nutrients, total organic carbon, biochemical oxygen demand, carbonaceous biochemical oxygen demand, chlorophyll- $a$, pheophytin- $a$, and suspended sediment were sampled six times during 2006-07 at the two Cotton Bayou sites and the Hackberry Gully site. The six samples at one Cotton Bayou 
site and at the Hackberry Gully site also were analyzed for bacteria.

Stream-habitat data were collected at the two West Fork Double Bayou sites, one Cotton Bayou site, and the Hackberry Gully site three times during the study, in JulyAugust 2006, March 2007, and July-August 2007. At each site, a representative stream reach was selected and within this reach, five evenly-spaced stream transects were determined. At each transect, stream attributes (wetted channel width, water depth, bottom material, instream cover) and riparian attributes (bank slope and erosion potential, width of natural vegetation, type of vegetation, percentage tree canopy) were measured. Habitat quality index scores generally indicated "intermediate" aquatic life use at most reaches. Three habitat quality index scores (two at a West Fork Bayou reach and one at the Hackberry Gully reach) indicated "high" aquatic life use.

Benthic macroinvertebrate data were collected from a representative reach at each of the same four sites used for habitat evaluation. A total of 2,572 macroinvertebrate individuals from the four reaches were identified. Overall, the most abundant benthic macroinvertebrates belonged to the family Chironomidae (non-biting midges). Other abundant groups of benthic macroinvertebrates were the orders Ephemeroptera (mayflies) and Coleoptera (beetles), the subclass Oligochaeta, and the class Malacostraca. Insect taxa were more abundant than non-insect taxa at all reaches.

Benthic macroinvertebrate assemblages were scored using indicator metrics specified by TCEQ. Aquatic-life-use scores were "high" during all surveys at the Cotton Bayou reach and "intermediate" during all surveys at one West Fork Double Bayou reach. At the two remaining reaches, two surveys were "high" and one survey was "intermediate."

Fish surveys, at a representative reach of each of the same four sites used for habitat evaluation, used a combination of seining and electrofishing methods. Fish collected using the seining method were kept separate from fish collected using the electrofishing method for identification and enumeration so that the effectiveness of each method could be assessed. After collection and identification at the stream, the fish were released.

Thirty species of fish representing 13 families were collected from West Fork Double Bayou, Cotton Bayou, and Hackberry Gully. A total of 1,082 fish were collected. Western mosquitofish was the most abundant species with 406 individuals collected. Several species were represented by only one individual: lined sole, alligator gar, and channel catfish.

An index of biotic integrity was calculated for the combined catch at each reach using scoring indexes developed to assess stream fish assemblages in the Western Gulf Coastal Plain. Index of biotic integrity scores indicated "high" aquatic life use during two surveys and "intermediate" aquatic life use during one survey at one West Fork Double Bayou reach; "intermediate" aquatic life use during all three surveys at the other West Fork Double Bayou reach; and "high" aquatic life use during one survey each at the Cotton Bayou and
Hackberry Gully reaches and "intermediate" aquatic life use during two surveys at each of those reaches.

\section{References}

Brasher, A.M.D., Wolff, R.H., and Luton, C.D., 2003, Associations among land use, habitat characteristics, and invertebrate community structure in nine streams of the island of Oahu, Hawaii, 1999-2001: U.S. Geological Survey WaterResources Investigations Report 03-4256, 47 p.

Delzer, G.C., and McKenzie, S.W., 2003, Five-day biochemical oxygen demand: U.S. Geological Survey Techniques of Water-Resources Investigations, book 9, chap. A7, section 7.0, available at http://pubs.water.usgs.gov/twri9A7/.

Fishman, M.J., ed., 1993, Methods of analysis by the U.S. Geological Survey National Water Quality LaboratoryDetermination of inorganic and organic constituents in water and fluvial sediments: U.S. Geological Survey OpenFile Report 93-125, 217 p.

Fishman, M.J., and Friedman, L.C., 1989, Methods for determination of inorganic substances in water and fluvial sediments: U.S. Geological Survey Techniques of WaterResources Investigations, book 5, chap. A1, 545 p.

Fram, M., 2006, Most fish kills in ponds are caused by low dissolved oxygen: Oklahoma State University, Oklahoma Cooperative Extension Service, accessed February 1, 2006, at http://biosystems.okstate.edu/waterquality/ Projects_Programs/Pond\%20management/Fish\% 20kills-low\%20DO.htm

Guy, H.P., 1969, Laboratory theory and methods for sediment analysis: U.S. Geological Survey Techniques of WaterResources Investigations, book 5, ch. C1, 58 p.

Hem, J.D., 1985, Study and interpretation of the chemical characteristics of natural water ( $3 \mathrm{~d}$ ed.): U.S. Geological Survey Water-Supply Paper 2254, 263 p.

Larkin, T.J., and Bomar, G.W., 1983, Climatic atlas of Texas: Texas Department of Water Resources Report LP-192, $151 \mathrm{p}$.

Linam, G.W., and Kleinsasser, L.J., 1998, Classification of Texas freshwater fishes into trophic and tolerance groups: Texas Parks and Wildlife Department, River Studies Report No. 14,8 p.

Linam, G.W., Kleinsasser, L.J., and Mayes, K.B., 2002, Regionalization of the index of biotic integrity for Texas streams: Texas Parks and Wildlife Department, Report No. $17,26 \mathrm{p}$.

Moring, J.B., 2003, Baseline assessment of fish communities, benthic macroinvertebrate communities, and stream habitat and land use, Big Thicket National Preserve, Texas, 
1999-2001: U.S. Geological Survey Water-Resources Investigations Report 03-4270, 33 p.

Mueller, D.K., Martin, J.D., and Lopes, T.J., 1997, Qualitycontrol design for surface-water sampling in the National Water-Quality Assessment Program: U.S. Geological Survey Open-File Report 97-223, 17 p.

Myers, D.N., Stoeckel, D.M., Bushon, R.N., Francy, D.S., and Brady, A.M.G., 2007, Fecal indicator bacteria (version 2.0): U.S. Geological Survey Techniques of Water-Resources Investigations, book 9, chap. A7, section 7.1, available at http://pubs.water.usgs.gov/twri9A7/.

National Climatic Data Center, 2006, Climatological data annual summary, Texas, 2006: v. 111, no. 13, accessed April 30, 2008, at http://www.ncdc.noaa.gov/oa/ncdc.html

National Climatic Data Center, 2007, Climatological data, Texas, January-August 2007: v. 112, nos. 1-8, accessed April 30, 2008, at http://www.ncdc.noaa.gov/oa/ncdc.html

Patton, C.J., and Truitt, E.P., 1992, Methods of analysis by the U.S. Geological Survey National Water Quality Laboratory-Determination of total phosphorus by a Kjeldahl digestion method and an automated colorimetric finish that includes dialysis: U.S. Geological Survey Open-File Report 92-146, 39 p.

Patton, C.J., and Truitt, E.P., 2000, Methods of analysis by the U.S. Geological Survey National Water Quality Laboratory-Determination of ammonium plus organic nitrogen by a Kjeldahl digestion method and an automated photometric finish that includes digest cleanup by gas diffusion: U.S. Geological Survey Open-File Report 00-170, 31 p.

Porter, S.D., Cuffney, T.F., Gurtz, M.E., and Meador, M.R., 1993, Methods for collecting algal samples as part of the National Water-Quality Assessment Program: U.S. Geological Survey Open-File Report 93-409, 39 p.

Powers, S.L., Jones, G.L., Redinger, P., and Mayden, R.L., 2003, Habitat associations with upland stream fish assemblages in Bankhead National Forest, Alabama: Southeastern Naturalist, v. 2, p. 85-92.

Sawyer, C.N., and McCarty, P.L., 1978, Chemistry for environmental engineering: New York, McGraw-Hill, p. 416-432.

Skrobialowski, S.C., Mize, S.V., and Demcheck, D.K., 2004, Environmental setting, water quality, and ecological indicators of surface-water quality in the Mermentau River Basin, southwestern Louisiana, 1998-2001: U.S. Geological Survey Water-Resources Investigations Report 03-4185, 73 p.

Stauffer, J.C., Goldstein, R.M., and Newman, R.M., 2000, Relationship of wooded riparian zones and runoff to fish community composition in agricultural streams: Canadian Journal of Fisheries and Aquatic Sciences, v. 57, p. 307-316.
Texas Administrative Code, 2007, Chapter 220, subchapter A, Program for monitoring and assessment of water quality by watershed and river basin: accessed August 20, 2007, at http://info.sos.state.tx.us/pls/pub/readtac\$ext.viewtac? tac_view $=4 \& t i=30 \& p t=1 \& c h=220$

Texas Commission on Environmental Quality, 2003a, Guidance for assessing Texas surface and finished drinking water quality data, 2004: accessed August 11, 2008, at http://www.tceq.state.tx.us/assets/public/compliance/ monops/water/04twqi/04_guidance.pdf

Texas Commission on Environmental Quality, 2003b, Surface water quality monitoring procedures-Volume 1 . Physical and chemical monitoring methods for water, sediment, and tissue: accessed June 27, 2008, at http://www.tceq.state. tx.us/comm_exec/forms_pubs/pubs/rg/rg-415/index.html

Texas Commission on Environmental Quality, 2007, Surface water quality monitoring procedures-Volume 2 . Methods for collecting and analyzing biological assemblage and habitat data: Texas Commission on Environmental Quality, Regulatory Guidance RG-416, 202 p.

Texas Commission on Environmental Quality, 2008, 2008 Texas water quality inventory and 303(d) list, 2008 index of water quality impairments (March 19, 2008): accessed October 27, 2008, at http://www.tceq.state.tx.us/ compliance/monitoring/water/quality/data/08twqi/ twqi08.html

Texas Natural Resource Conservation Commission, 1999, Receiving water assessment procedures manual: Texas Natural Resource Conservation Commission, Water Quality Division, GI-253 [variously paged].

Thomas, L.P., Peitz, D.G., and Carlisle, D.M., 2002, Macroinvertebrate monitoring as an indicator of water qualityStatus report for Wilson's Creek and Skegg's Branch, Wilson's Creek National Battlefield, 1998-2001: National Park Service, accessed February 9, 2006, at $h t t p: / / w w w$. nature.nps.gov/im/units/htln/pdf/Reports/NPS\%20WICR\% 20Macroinvertebrate\%20Report\%202001\%20DEC\% 2020\%20Complete.pdf

U.S. Environmental Protection Agency, 1993, Methods for the determination of inorganic substances in environmental samples: U.S. Environmental Protection Agency, Office of Research and Development, EPA-600/R-93-100, 79 p.

Vannote, R.L., Minshall, G.W., Cummins, K.W., Schell, J.R., and Cushing, C.E., 1980, The river continuum concept: Canadian Journal of Fisheries and Aquatic Sciences, v. 37, p. $130-137$.

Wershaw, R.L., Fishman, M.J., Grabbe, R.R., and Lowe, L.E., eds., 1987, Methods for the determination of organic substances in water and fluvial sediments: U.S. Geological Survey Techniques of Water-Resources Investigations, book 5 , chap. A3, $80 \mathrm{p}$. 
Blank Page 
Appendixes 1-6 


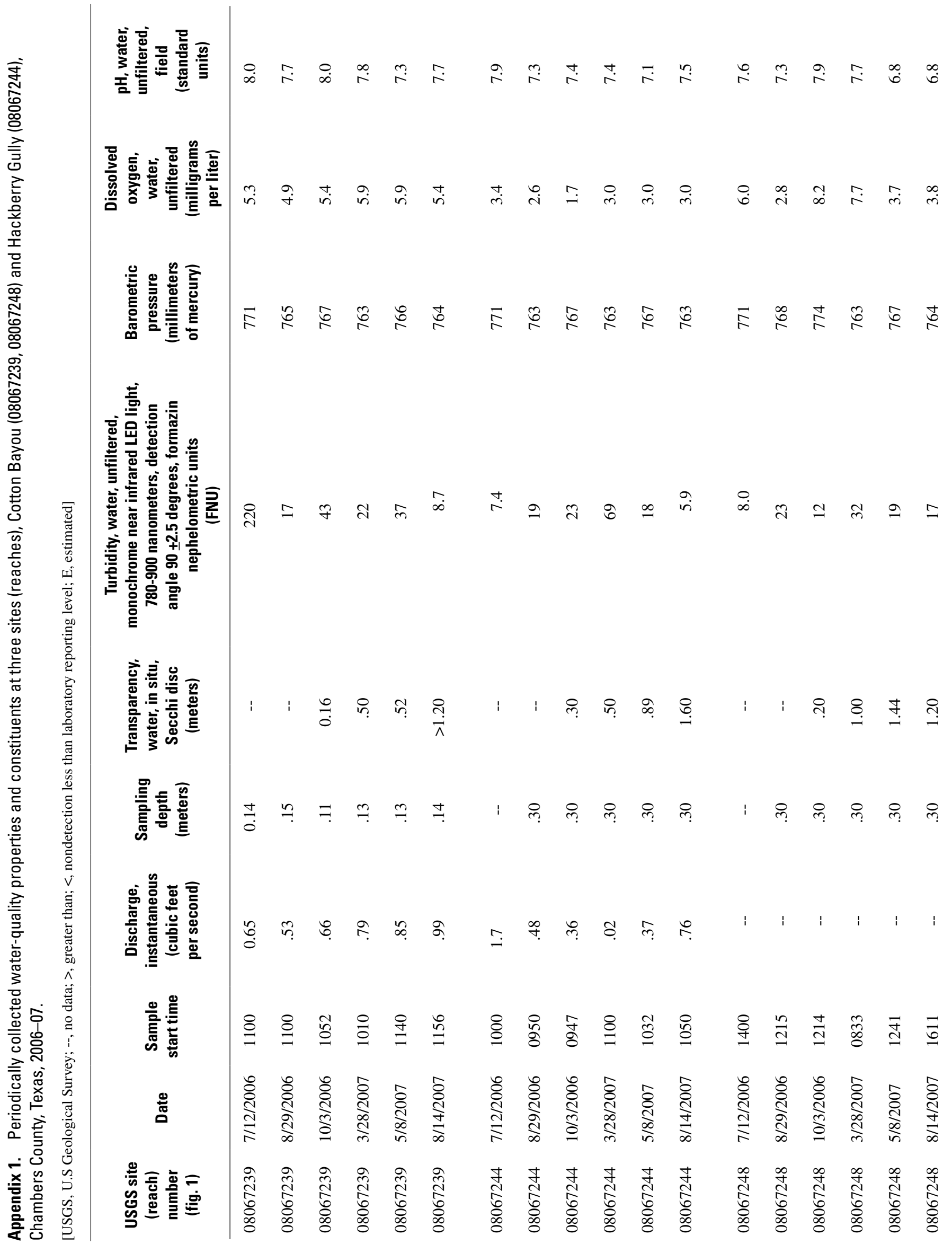




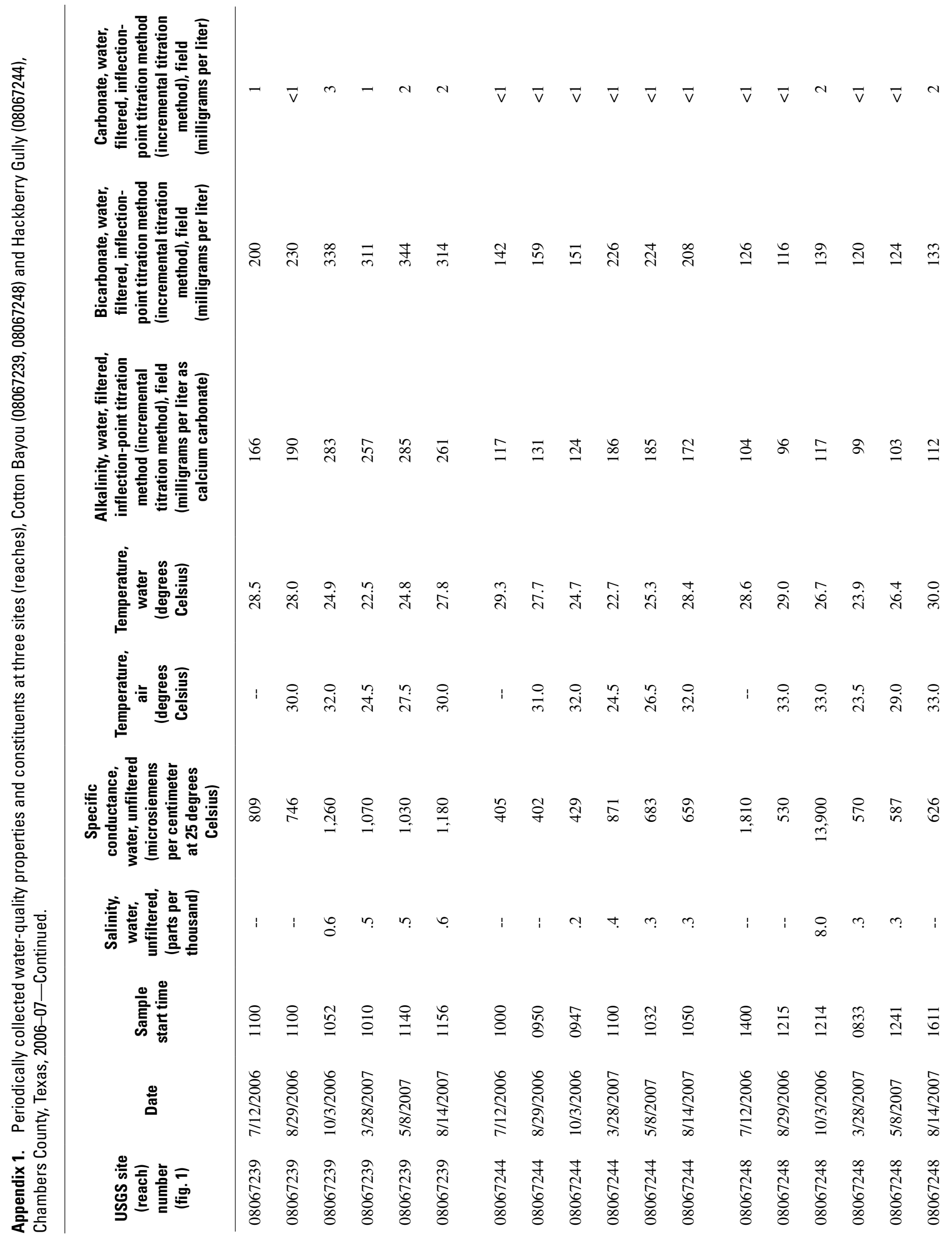




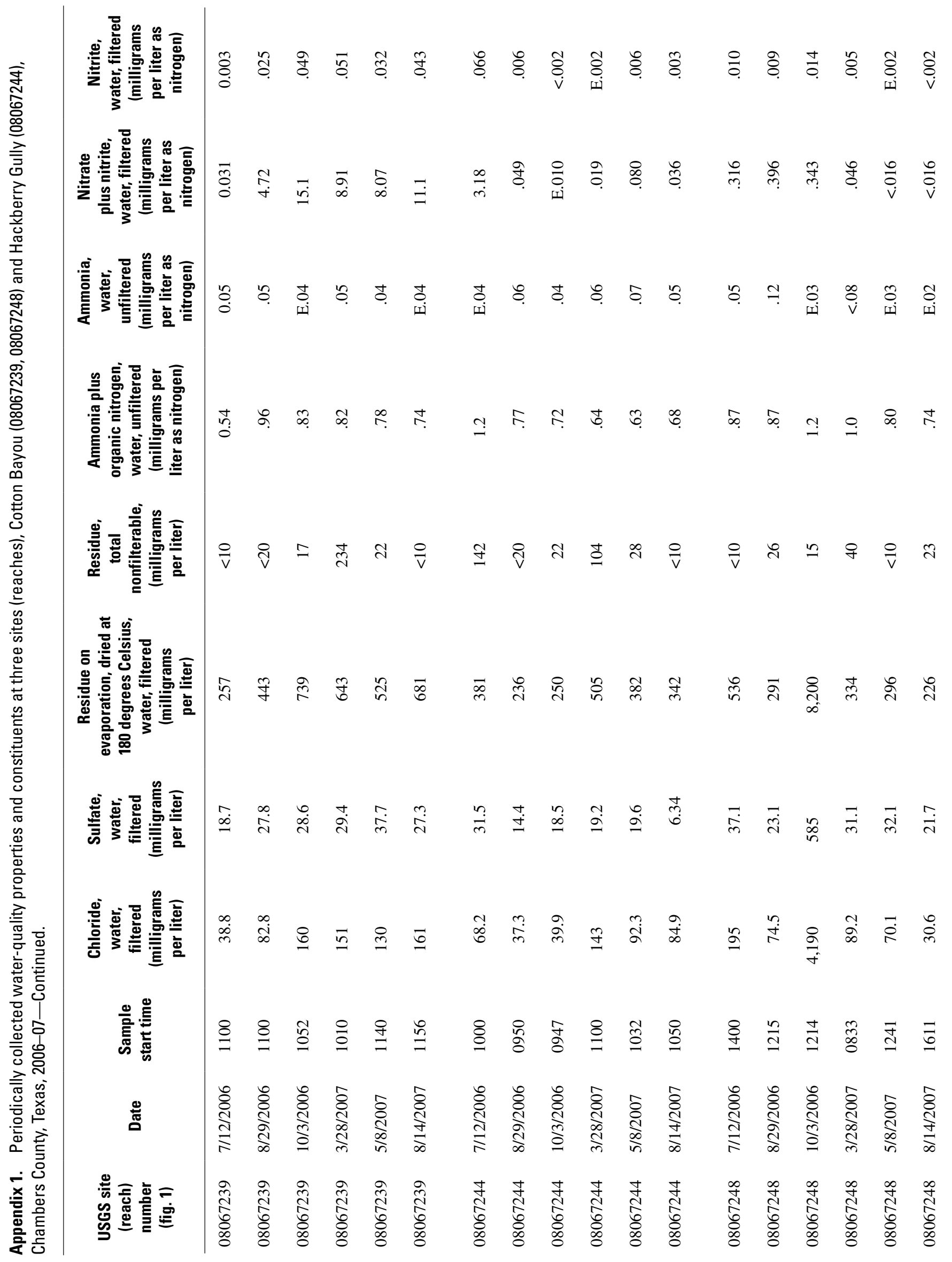




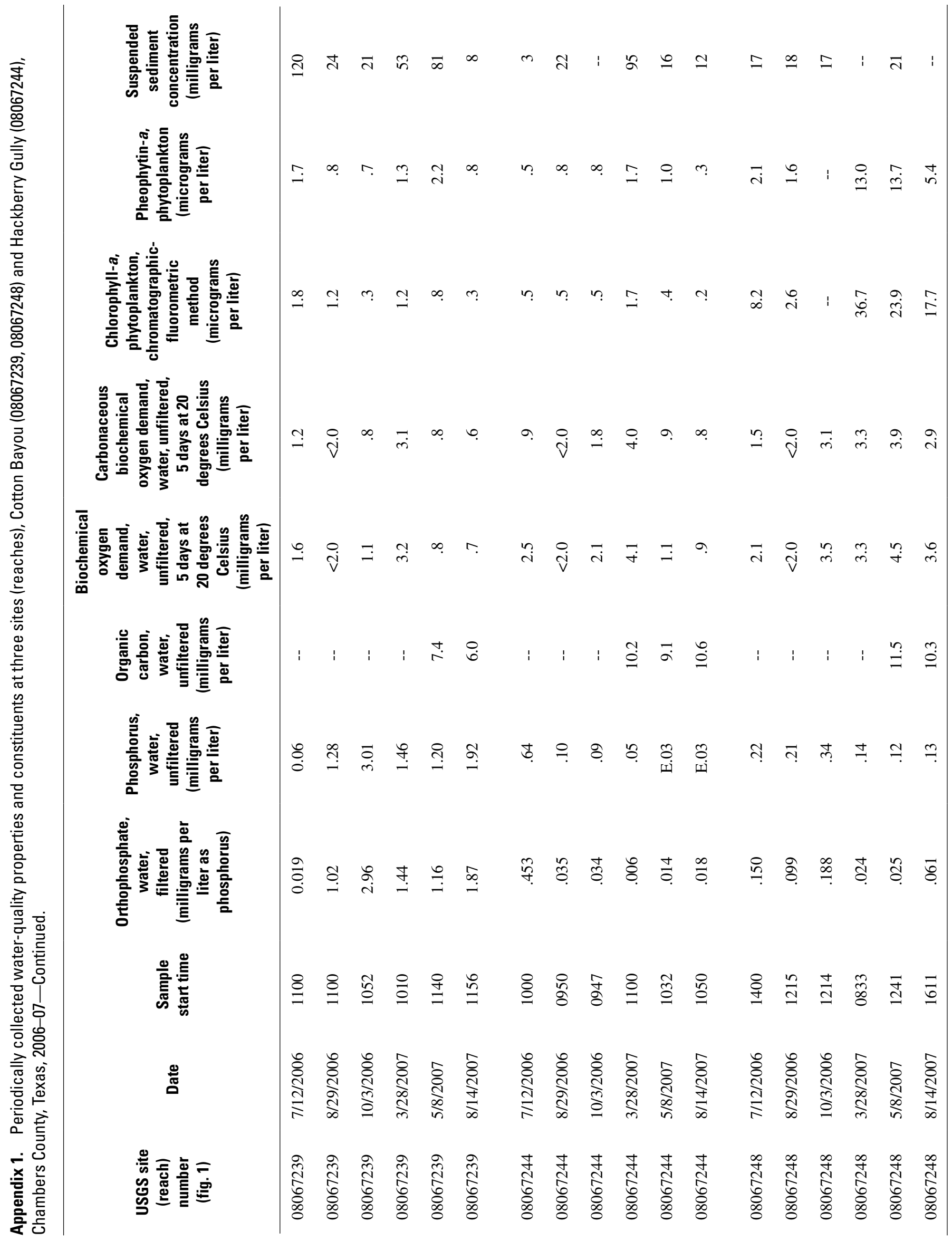




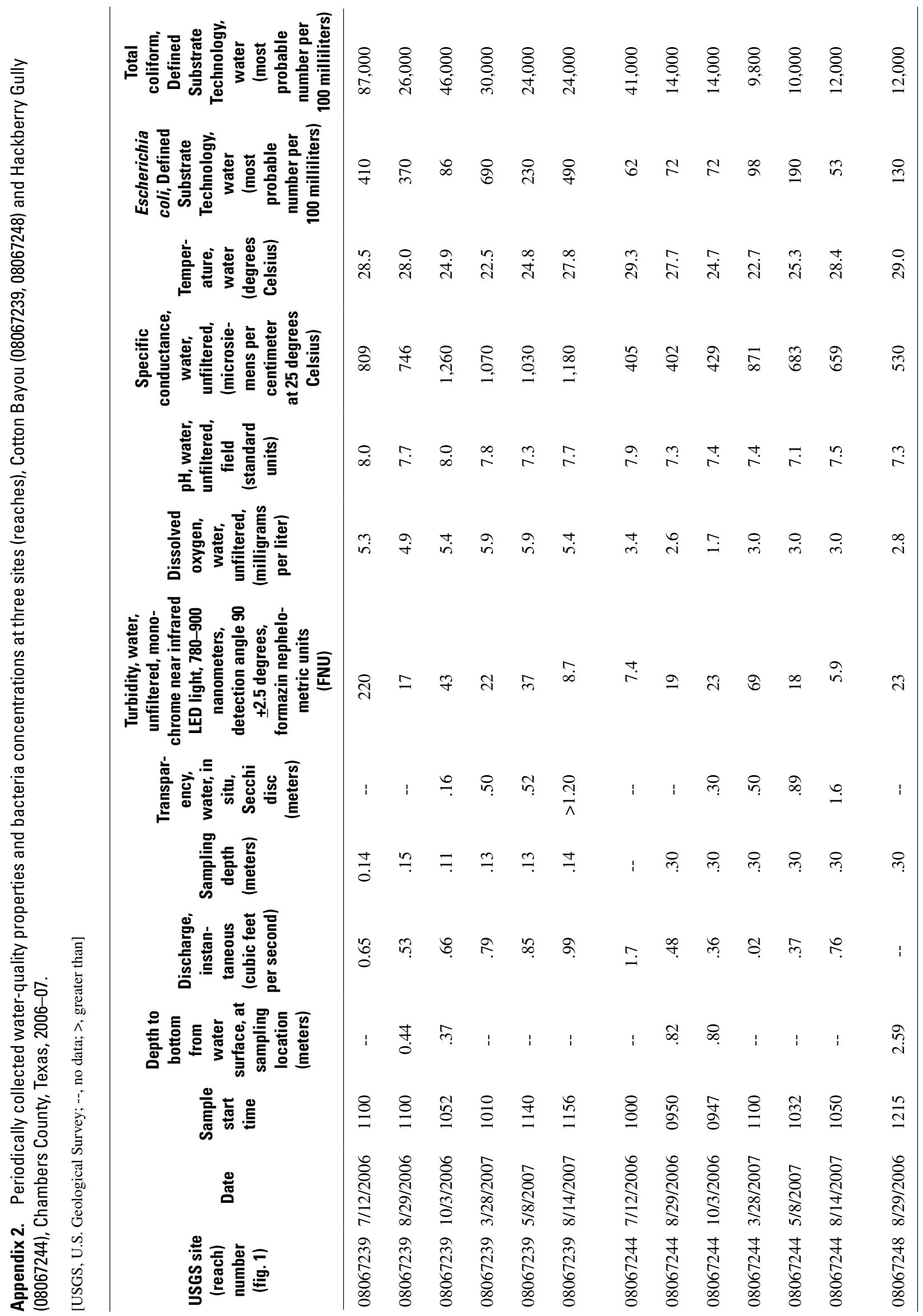



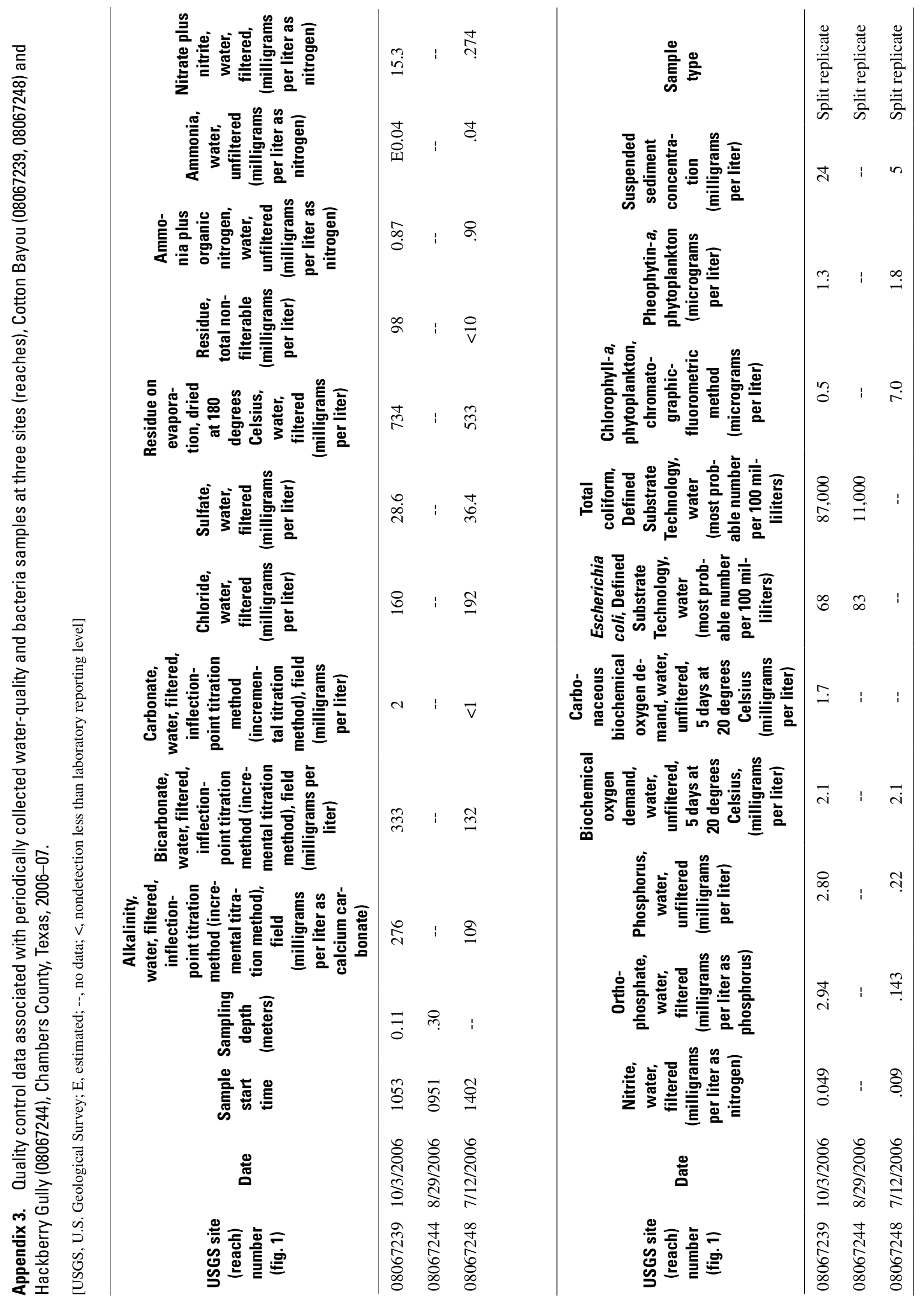


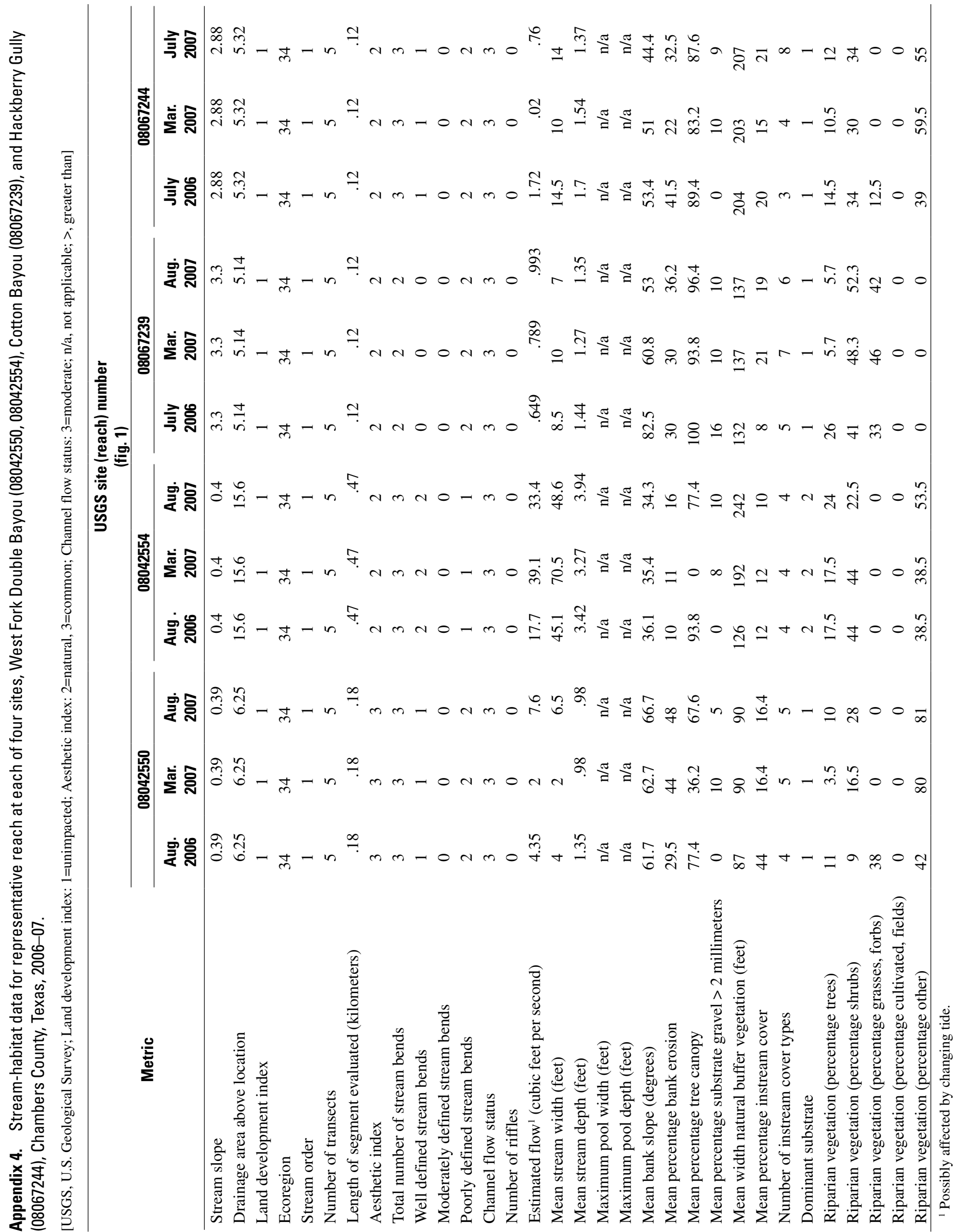




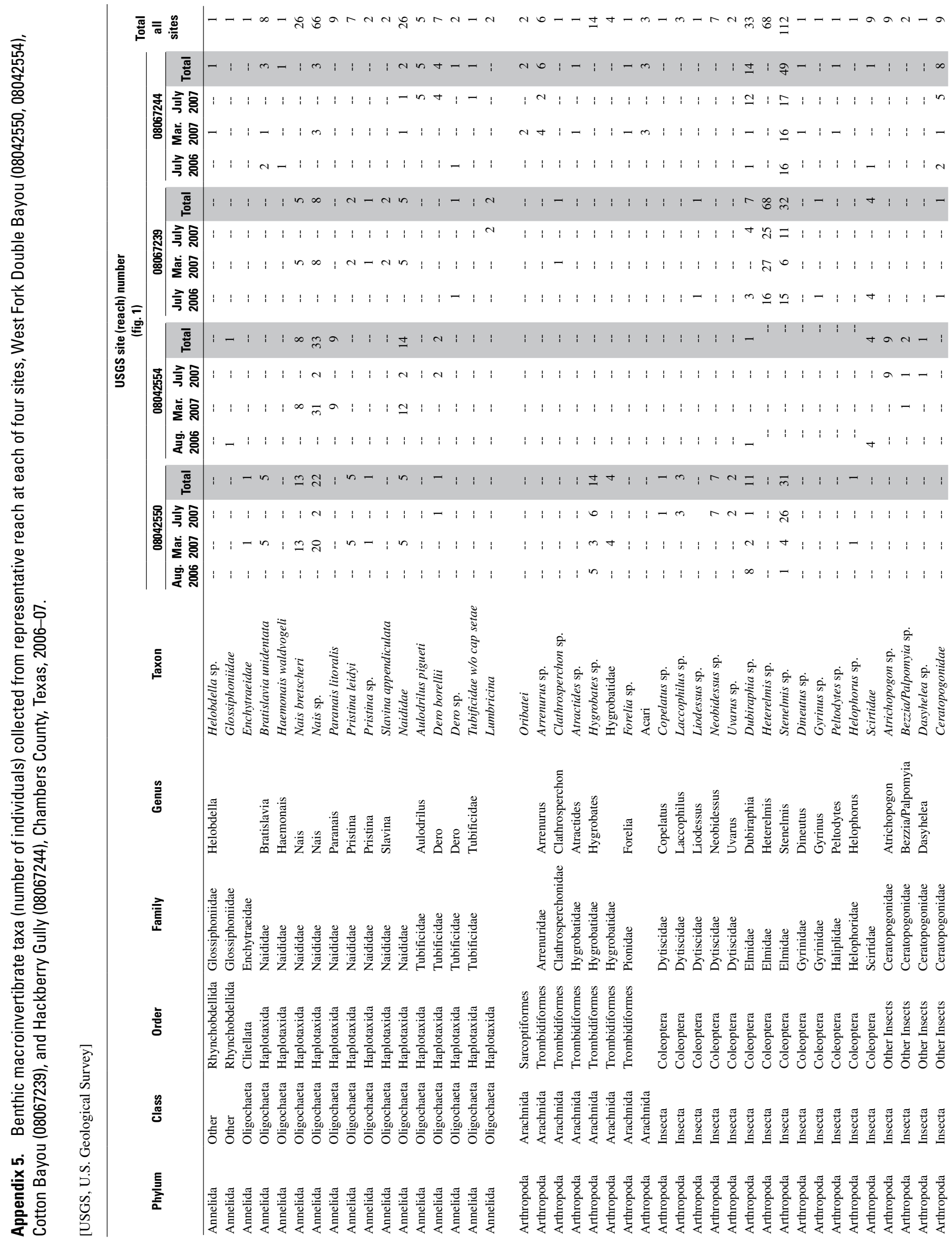


殄

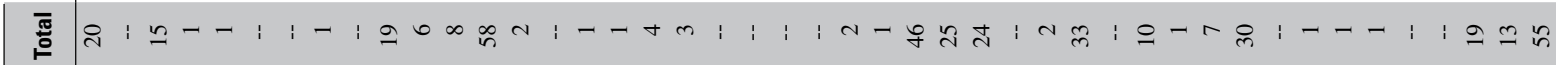

胥

免

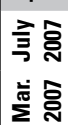

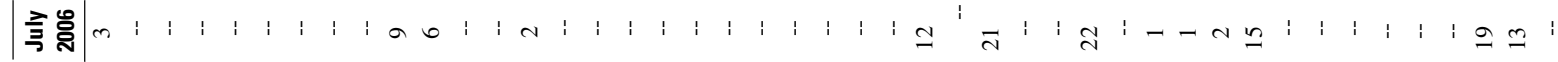

急 $\infty: \varrho:$ :

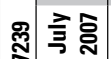

穴

离

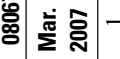

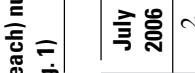

필

芠

츨

变茴

in

$\begin{array}{llllllllllllllll}1 & 1 & 1 & 1 & 1 & 1 & 1 & 1 & 1 & 1 & 1 & 1 & 1 & 1 & 1 & \end{array}$

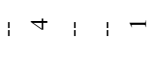

-

i

i i i

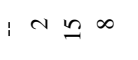

i 2

$\pm i$

i 6

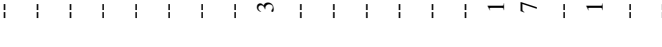

$1=$

$\stackrel{\infty}{-1}$

i $a$

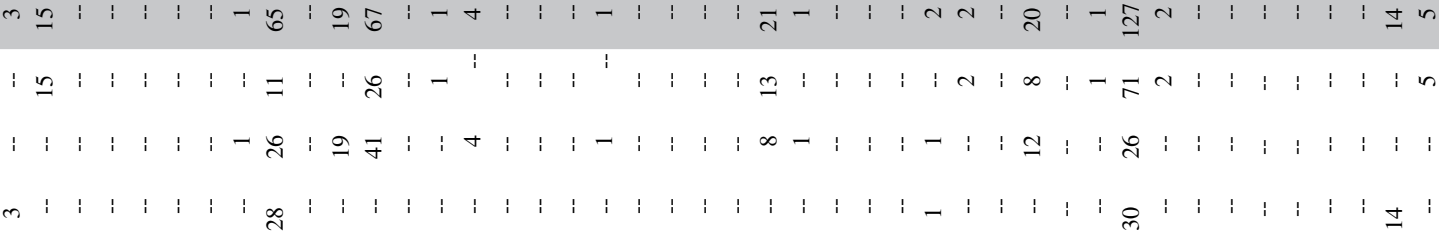

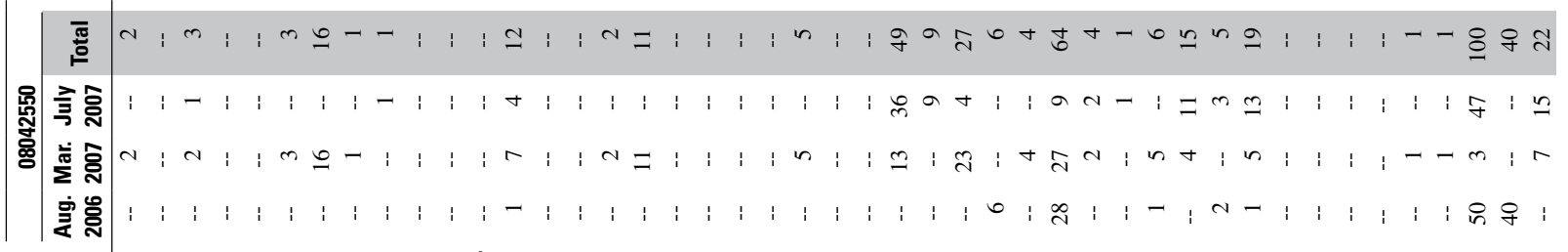

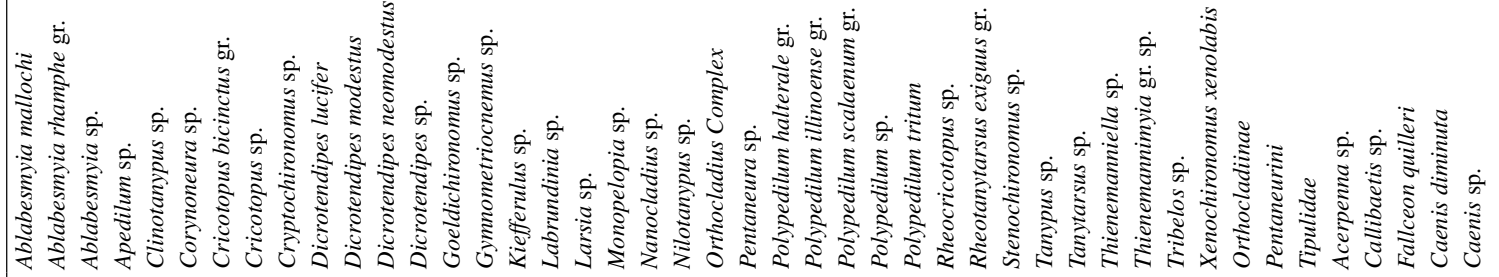

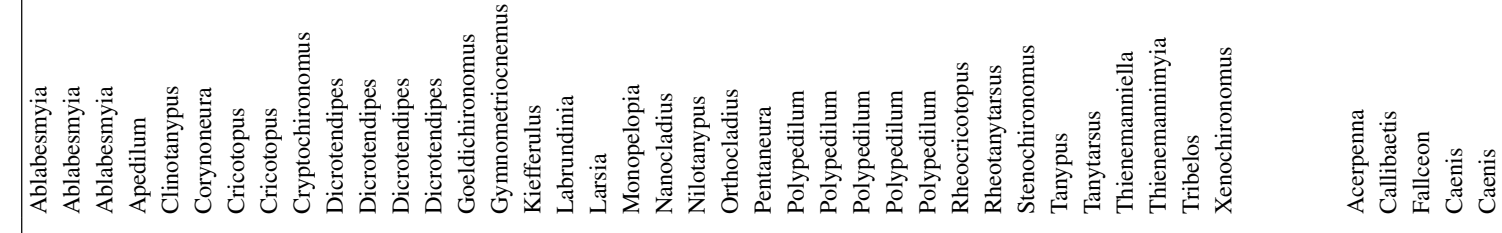

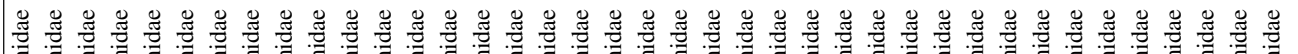

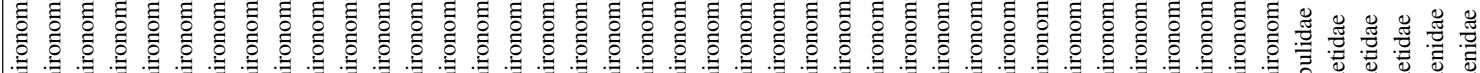

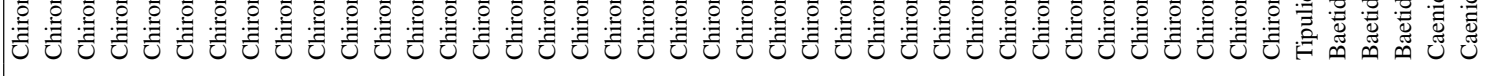

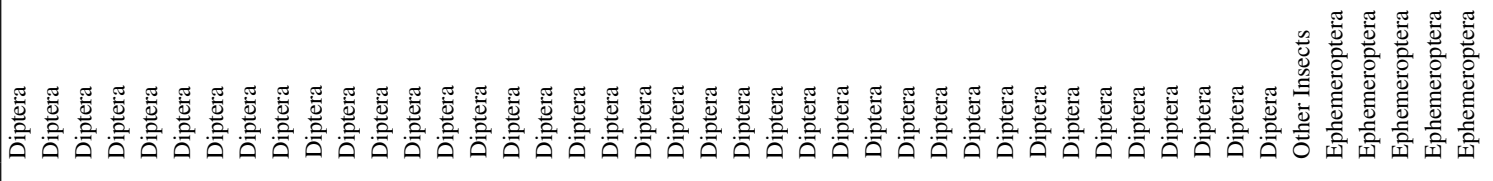




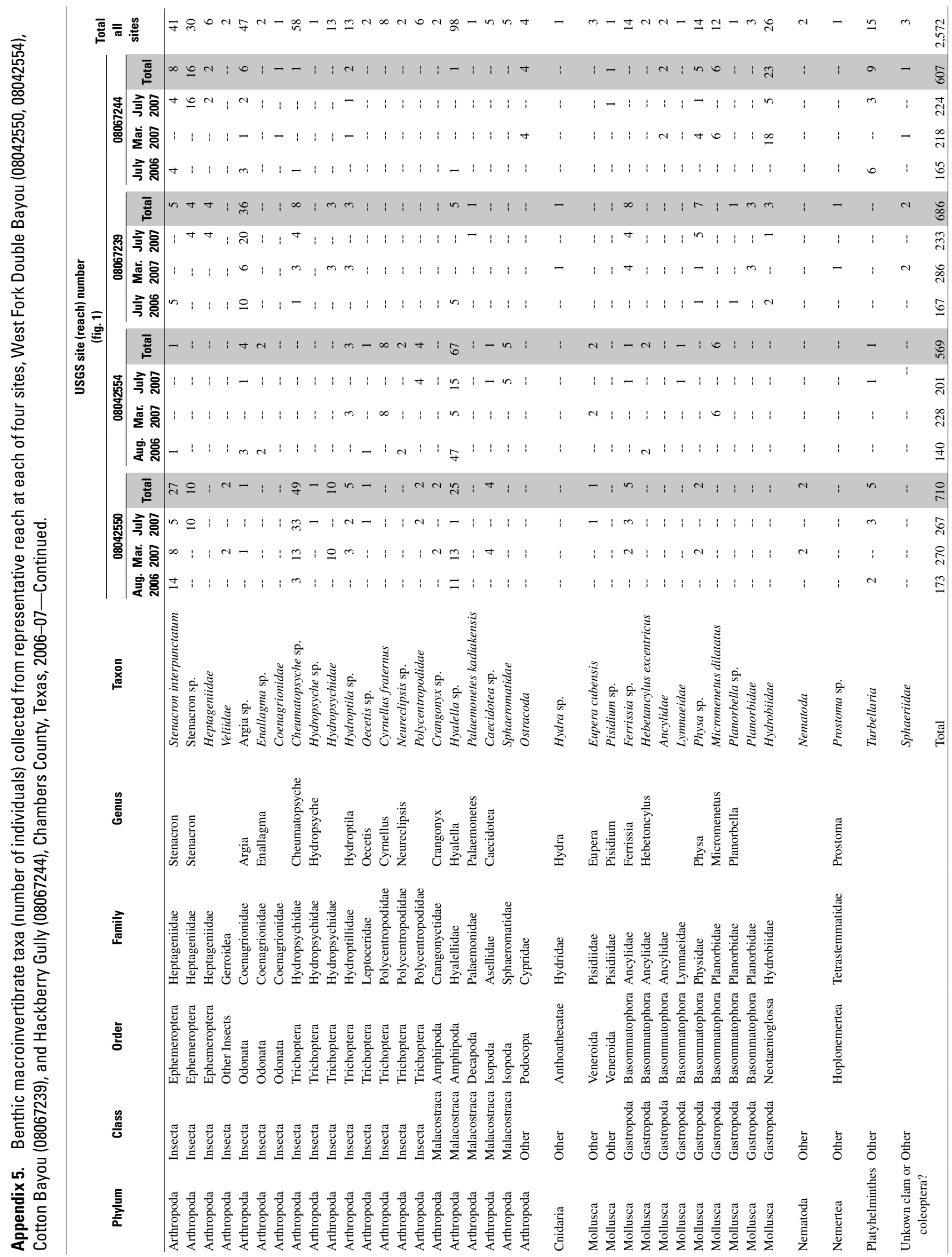




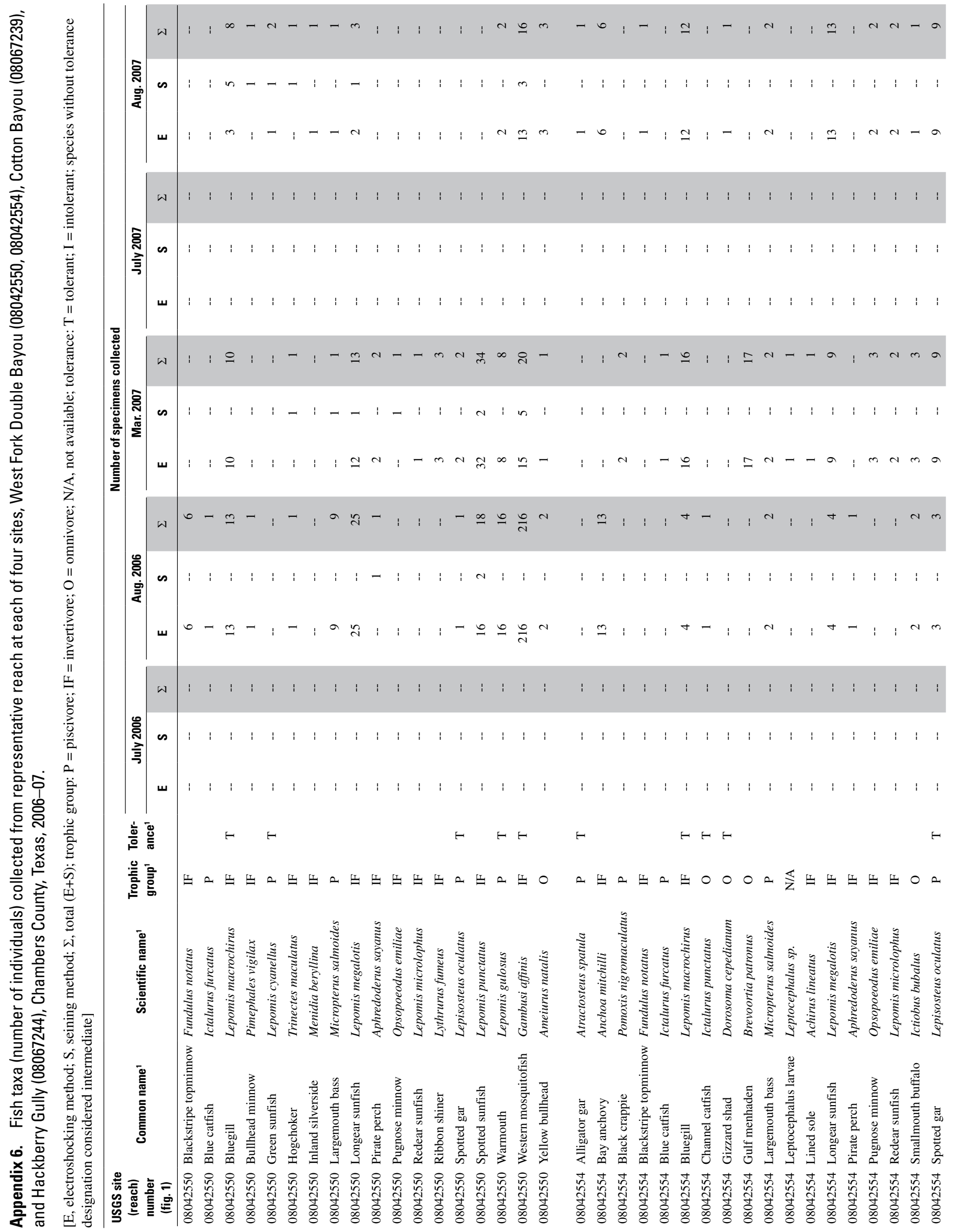




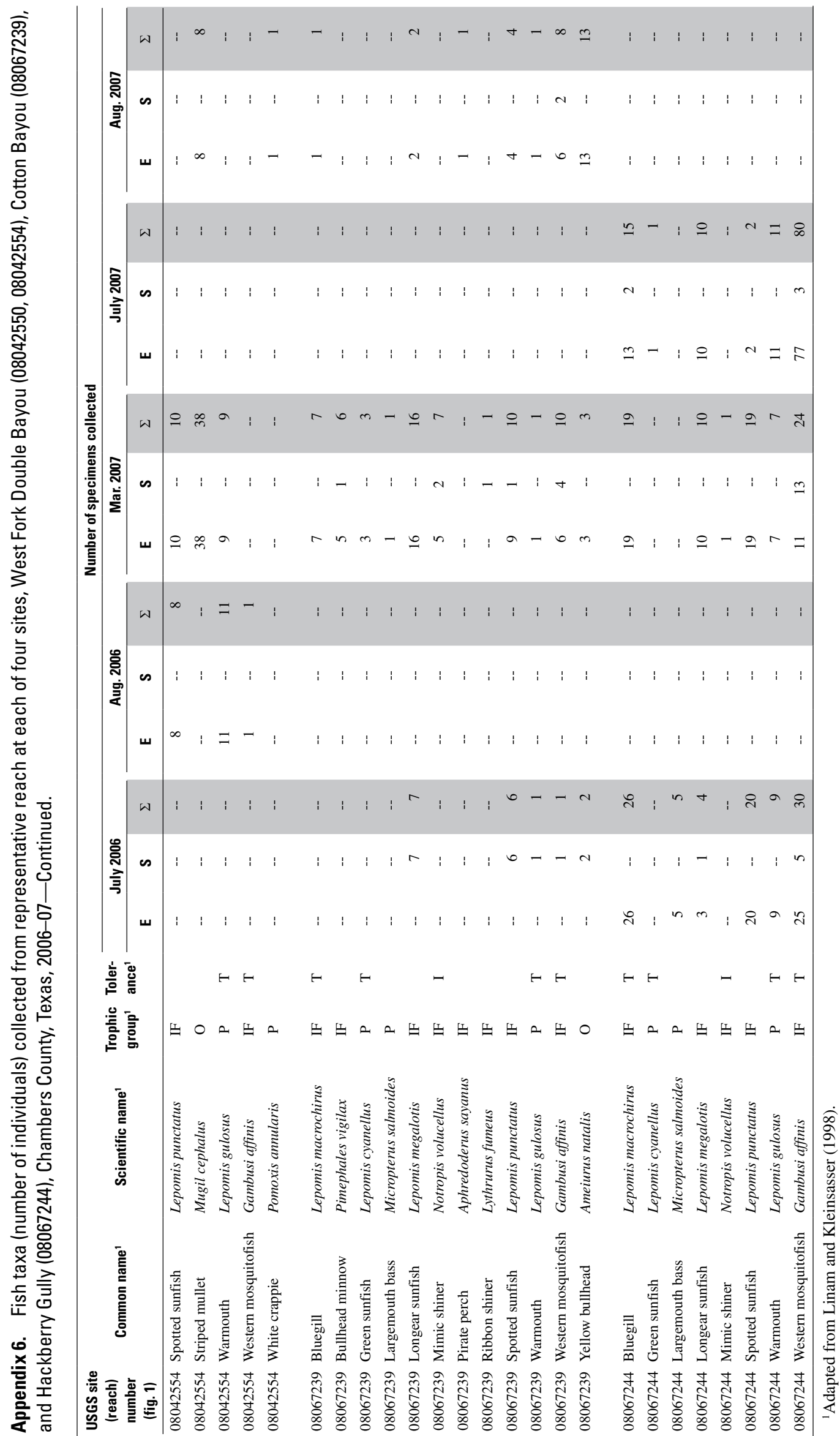


Publishing support provided by Lafayette Publishing Service Center

Information regarding water resources in Texas is available at http://tx.usgs.gov/ 


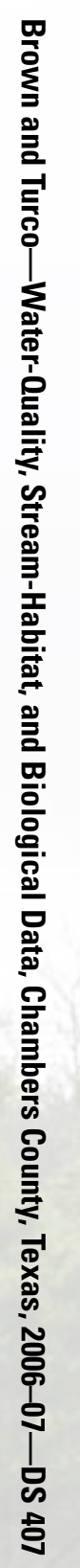

Printed on recycled paper 